\title{
Nrf2-interacting nutrients and COVID-19: time for research to develop adaptation strategies
}

\author{
Jean Bousquet ${ }^{1,2,3^{*}}$ (D) Jean-Paul Cristol ${ }^{4}$, Wienczyslawa Czarlewski ${ }^{5,6}$, Josep M. Anto ${ }^{7,8,9,10}$, Adrian Martineau ${ }^{11}$, \\ Tari Haahtela ${ }^{12}$, Susana C. Fonseca ${ }^{13}$, Guido laccarino ${ }^{14}$, Hubert Blain ${ }^{15}$, Alessandro Fiocchi ${ }^{16}$, \\ G. Walter Canonica ${ }^{17}$, Joao A. Fonseca ${ }^{18}$, Alain Vidal ${ }^{19,20}$, Hak-Jong Choi ${ }^{21}$, Hyun Ju Kim ${ }^{22}$, Vincent Le Moing ${ }^{23}$, \\ Jacques Reynes ${ }^{23}$, Aziz Sheikh ${ }^{24}$, Cezmi A. Akdis ${ }^{25}$, Torsten Zuberbier ${ }^{1}$ and the ARIA group
}

\begin{abstract}
There are large between- and within-country variations in COVID-19 death rates. Some very low death rate settings such as Eastern Asia, Central Europe, the Balkans and Africa have a common feature of eating large quantities of fermented foods whose intake is associated with the activation of the Nrf2 (Nuclear factor (erythroid-derived 2)-like 2) anti-oxidant transcription factor. There are many Nrf2-interacting nutrients (berberine, curcumin, epigallocatechin gallate, genistein, quercetin, resveratrol, sulforaphane) that all act similarly to reduce insulin resistance, endothelial damage, lung injury and cytokine storm. They also act on the same mechanisms (mTOR: Mammalian target of rapamycin, PPARY:Peroxisome proliferator-activated receptor, NFkB: Nuclear factor kappa B, ERK: Extracellular signal-regulated kinases and elF2a:Elongation initiation factor $2 a$ ). They may as a result be important in mitigating the severity of COVID-19, acting through the endoplasmic reticulum stress or ACE-Angiotensin-II-AT ${ }_{1}$ axis $\left(A T_{1}\right.$ R) pathway. Many Nrf2-interacting nutrients are also interacting with TRPA1 and/or TRPV1. Interestingly, geographical areas with very low COVID-19 mortality are those with the lowest prevalence of obesity (Sub-Saharan Africa and Asia). It is tempting to propose that Nrf2-interacting foods and nutrients can re-balance insulin resistance and have a significant effect on COVID-19 severity. It is therefore possible that the intake of these foods may restore an optimal natural balance for the Nrf2 pathway and may be of interest in the mitigation of COVID-19 severity.
\end{abstract}

Keywords: COVID-19, Nrf2, Foods, Nutrients, Insulin resistance, Obesity, TRPA1

\section{Introduction}

Large differences in COVID-19 death rates exist between countries and regions of the same country. Like most diseases, COVID-19 exhibits large geographical variations which frequently remain unexplained. The COVID-19 epidemic is multifactorial, and factors like climate, population density, social distancing, age,

\footnotetext{
*Correspondence: jean.bousquet@orange.fr

1 Department of Dermatology and Allergy, Charité, Universitätsmedizin

Berlin, Humboldt-Universität Zu Berlin, Berlin Institute of Health, Comprehensive Allergy Center, Berlin, Germany

Full list of author information is available at the end of the article
}

phenotype, obesity and prevalence of non-communicable diseases are associated to increased incidence and mortality [1]. Diet represents only one of the possible causes of the COVID-19 epidemic [2,3]. Although there are many pitfalls in analyzing death rates for COVID-19, [3] death rates were low or very low in Central European countries, Eastern Asian countries, many Sub-Saharan African countries, the Middle East, India and Pakistan as well as Australia and New Zealand. This geographical pattern is very unlikely to be totally due to reporting differences between countries. Some very low death rate settings (but not Australia or New Zealand)

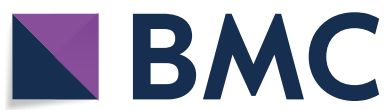

(c) The Author(s) 2020. This article is licensed under a Creative Commons Attribution 4.0 International License, which permits use, sharing, adaptation, distribution and reproduction in any medium or format, as long as you give appropriate credit to the original author(s) and the source, provide a link to the Creative Commons licence, and indicate if changes were made. The images or other third party material in this article are included in the article's Creative Commons licence, unless indicated otherwise in a credit line to the material. If material is not included in the article's Creative Commons licence and your intended use is not permitted by statutory regulation or exceeds the permitted use, you will need to obtain permission directly from the copyright holder. To view a copy of this licence, visit http://creativeco mmons.org/licenses/by/4.0/. The Creative Commons Public Domain Dedication waiver (http://creativecommons.org/publicdomain/ zero/1.0/) applies to the data made available in this article, unless otherwise stated in a credit line to the data. 
have a common feature of eating large quantities of fermented vegetables such as cabbage, other members of the Brassicaceae family and, in some continents, various spices [4]. Notwithstanding the fact that data from ecological studies need to be interpreted with caution, fermented vegetables or cabbage have been found to be associated with low COVID-19 death rates in European countries [5-7].

Reactive oxygen species (ROS) exert beneficial and toxic effects on cellular functions. Nrf2 is a pleiotropic transcription factor protecting against oxidative stress. It expresses a wide array of genes involved in immunity and inflammation, including antiviral actions [8]. Several Nrf2-interacting natural compounds (e.g. berberine, curcumin, epigallocatechin gallate, genistein, quercetin, resveratrol, sulforaphane) and lactobacilli acting as antioxidants are effective against insulin resistance associated diseases [9]. They may be important in the mitigation of COVID-19 [5, 9, 10], acting through the endoplasmic reticulum (ER) [11-13] or ACE-Angiotensin-II- $\mathrm{AT}_{1} \mathrm{R}$ axis $\left(\mathrm{AT}_{1} \mathrm{R}\right)$ pathway $[3,5]$ and leading to insulin resistance (IR), endothelial damage, lung injury and cytokine storm. They may also interact with SARS-CoV-2 by other pathways involved in IR that may be Nrf2-dependent or -independent [11-13].

Obesity is a very important risk factor for COVID19 severity [14] and is often associated with diet. There may be interactions between obesity, diet and COVID19, possibly linked with Nrf2 [15].

The present rostrum follows the first two papers on diet and COVID-19 from our group [3, 5]. Specifically, we seek to (i) expand discussion on the role of Nrf2interacting natural nutrients in IR, (ii) assess the mechanisms on ER stress and the $\mathrm{AT}_{1} \mathrm{R}$ pathway, and (iii) understand how Nrf2-interacting nutrients can interplay to mitigate COVID- 19 .

\section{Nrf2-interacting nutrients}

The most common Nrf2 nutrients include berberine, curcumin, epigallocatechin gallate (EGCG), genistein, quercetin, resveratrol, sulforaphane mostly found in vegetables and fruits, and Lactobacillus in fermented foods (Table 1). We did not want to be exhaustive and we did not examine other nutrients such as brassinin or the the organosulfide diallyl trisulfide.

Herbs, fruits or vegetables such as garlic [16] or kiwi can also have antioxidant activities mediated by Nrf2 [9].

Micronutrients such as Zinc, Chromium, Selenium [17] and vitamin D [18] possess antioxidant activities associated, at least partly, with activation of Nrf2.

\section{Cellular response to SARS-CoV-2}

\section{Endoplasmic reticulum stress response and Coronavirus}

The coronavirus infection triggers ER stress responses in infected cells associated with increased levels of reactive oxygen species (ROS) and unfolded protein response (UPR) [19-21]. As a general response, ER stress leads to PERK phosphorylation of the elongation initiation factor $2 \alpha$ (eIF2 $\alpha$ ) and of Nrf2 [22]. Activated PERK inactivates eIF2 $\alpha$, leading to a decrease in overall protein synthesis. Phosphorylation of PKR and PERK has been observed in SARS-CoV-2-infected cells [23]. ERK/MAPK and PI3K/AKT/mTOR signalling responses play important roles in Middle East respiratory syndrome coronavirus (MERS-CoV) infection [24]. The key role in the synthesis of proteins essential for these mechanisms belongs to mTOR (mammalian target of rapamycin) complexes and signalling pathways involved in mTOR regulation including eIF2 $\alpha$ [25]. mTOR is a serine/threonine protein kinase in the PI3K-related kinase (PIKK) family that forms the catalytic subunit of two distinct protein complexes, known as mTOR Complex 1 (mTORC1) and 2 (mTORC2). The mTOR pathway functions as a central regulator

Table 1 Origin of Nfr2-interacting nutrients

\begin{tabular}{|c|c|c|}
\hline \multicolumn{2}{|l|}{ Nutrient } & \multirow{2}{*}{$\begin{array}{l}\text { Foods containing nutrient } \\
\text { European barberry, goldenseal, goldthread, Oregon grape, phellodendron, goldenseal, poppy, and } \\
\text { tree turmeric }\end{array}$} \\
\hline Berberine & Benzylisoquinoline alkaloid & \\
\hline Curcumin & Curcuminoid (phenol) & Turmeric \\
\hline EGCG & Catechin (polyphenol) & Green and white tea \\
\hline Genistein & Soy isoflavone & Soy-based foods including tofu, tempeh and miso \\
\hline Lactobacillus & Lactic acid bacteria & Fermented foods \\
\hline Quercetin & Flavonoid group of polyphenols & $\begin{array}{l}\text { Found in many fruits (cranberries, lingonberries, black plums), vegetables (broccoli, capers, kale, red } \\
\text { onion, radish, sorel, watercress), leaves (fennel), seeds, and grains }\end{array}$ \\
\hline Resveratrol & Stilbenoid (phenol) & Skin of grapes, blueberries, raspberries, mulberries and peanuts \\
\hline Sulforaphane & Isothiocyanate & Cruciferous vegetables such as broccoli, Brussels sprouts, and cabbages \\
\hline
\end{tabular}

EGCG, Epigallocatechin gallate 
of cell metabolism, growth, proliferation, and survival. mTORC1 mainly functions as a nutrient/energy/redox sensor and controls protein synthesis, lipid metabolism, and organelle biogenesis [26]. mTORC2 promotes the activation of insulin receptors and insulin-like growth factor 1 receptors. mTORC1 and C2 complexes are activated by nutrients, growth factors, and inflammatory mediators.

ER stress and sustained UPR signalling are major contributors to the pathogenesis of several diseases, including inflammatory disorders and viral infections [27] and can increase the severity of these events [28]. ER stress has an important role in cardiovascular and metabolic disease, obesity and in diabetes $[29,30]$ and pancreatic $ß$-cell dysfunction, often through mTOR [31]. Oxidative stress is counter-balanced by complex antioxidant defence systems regulated by a series of multiple pathways, including the UPR, to ensure that the response to oxidants is adequate. Nrf2, interrelated with the UPR sensor called the pancreatic endoplasmic reticulum kinase, is a regulator of cellular resistance to oxidants $[22,32]$.

A recent study showed a disruption of mTOR signalling with increased levels of mTOR and a downregulation of eIF2 signalling in multiple cellular compartments of severe COVID-19 patients when compared to patients who recovered [33].

\section{AT ${ }_{1}$ R-associated effects}

Angiotensin II (AngII) is the predominant Renin-Angiotensin-Aldosterone system (RAAS) component contributing to IR [34]. The angiotensin-converting enzyme 2 (ACE2) receptor is part of the dual RAAS system consisting of an $\mathrm{AT}_{1} \mathrm{R}$ axis and an ACE-2-Angiotensin$(1,7)$-Mas axis. $\mathrm{AT}_{1} \mathrm{R}$ is involved in most of the effects of Ang II, including oxidative stress generation [35], which in turn upregulates $\mathrm{AT}_{1} \mathrm{R}$ [36]. In metabolic disorders and with older age, there is an upregulation of the $\mathrm{AT}_{1} \mathrm{R}$ axis leading to pro-inflammatory, pro-fibrotic effects in the respiratory system, endothelial damage and IR [37]. SARS-CoV-2 binds to its receptor ACE2 and exploits it for entry into the cell. The ACE2 downregulation, as a result of SARS-CoV-2 binding, enhances the $\mathrm{AT}_{1} \mathrm{R}$ axis [38] likely to be associated with IR $[39,40]$, but also with inflammation [41] and severe outcomes of COVID-19. Nrf2 is the most potent antioxidant in humans and can block the $\mathrm{AT}_{1} \mathrm{R}$ axis [8].

\section{Cross-talk between the renin-angiotensin-aldosterone system (RAAS) and the endoplasmic reticulum (Fig. 1)}

Several studies have shown an interaction of RAAS and ER in insulin resistance. Ang-II increases ER stress in adipose tissue [42]. ACE2 regulates intramuscular fat by improving ER and mitochondrial function [43]. On the other hand, Ang 1-7 protects against Ang II-induced ER

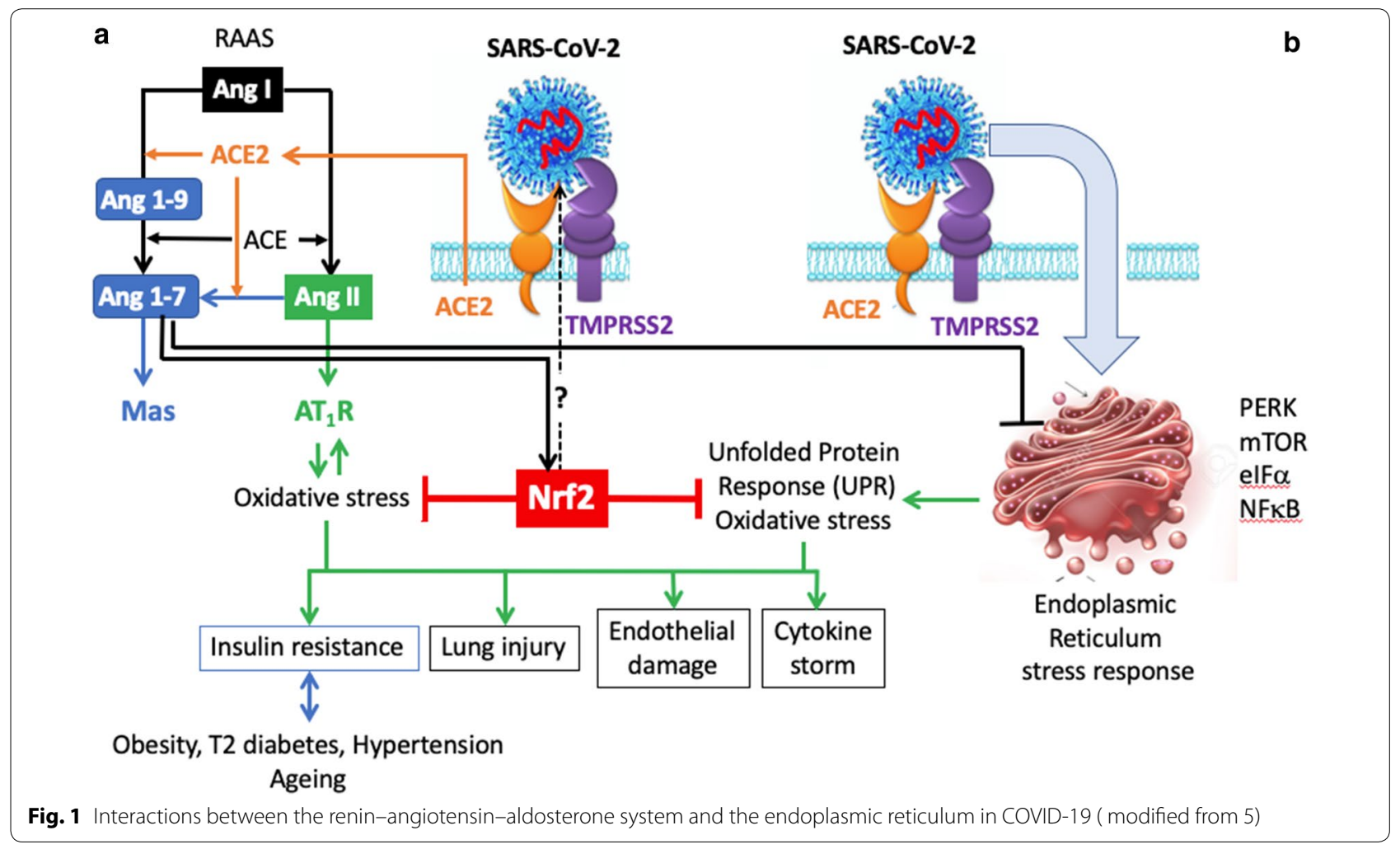


stress and endothelial dysfunction via the Mas receptor [44]. These mechanisms appear to be of great importance in COVID-19 and propose an interaction between ER stress and $\mathrm{AT}_{1} \mathrm{R} /$ Mas pathways with Nrf2 at the centre of the regulatory mechanism.

Moreover, in addition to reducing the production of infectious virions, the inhibition of ER glucosidases also impairs the entry of selected viruses via a post-receptorbinding mechanism [45].

\section{Nrf2 in cytokine storm, endothelium and lung damage}

The Nrf2 signalling pathway regulates anti-inflammatory gene expression and inhibits the progression of inflammation [46]. In particular, the upregulation of Nrf2 signalling inhibits the overproduction of IL-6, proinflammatory cytokines, and chemokines as well as limiting the activation of NFKB.

Failure to protect against oxidative stress-induced cellular damage leads to endothelial dysfunction in cardiovascular diseases and other pathologies associated with metabolic syndrome. Several antioxidant pathways are involved in cellular redox homeostasis, among which the Nrf2 signalling pathway is one of the most prominent [47].

Nrf2 induces cellular rescue pathways against oxidative pulmonary injury, abnormal inflammatory and immune responses, as well as apoptosis. The Nrf2 pathway can protect against various lung injuries including acute lung injury and acute respiratory distress syndrome [48].

\section{Autophagy}

Autophagy is the natural cell regulated mechanism leading to the degradation of components through the action of the lysosomal system to remove unnecessary or dysfunctional components. It is a constitutive pathway upregulated under stressful conditions including oxidative stress, [49] ER stress or viral infection. One key element of viral infection is the fate of the virus in the cell.

While autophagy has been shown to act as an anti-viral defence, human viruses use multiple steps in endocytic and autophagy pathways to help viral propagation and escape immune response [50, 51]. Coronaviruses have adapted by producing many strategies to escape or to benefit via the inhibition and/or stimulation of autophagy [52]. SARS-Cov-2 most likely impacts autophagy by several mechanisms [52-55] including highjacking the autophagy machinery for their intracellular survival (canonical) [54] and expressing specific proteins to usurp components of the autophagy pathway and propagate in host cells (noncanonical) [52].

The oxidative stress associated with increases in reactive oxygen species (ROS) is interconnected with autophagy [56, 57]. Oxidative stress leads to oxidative damage of proteins, lipids, and nucleic acids. Autophagy is crucial in ROS generation and scavenging damaged substrates, which is achieved by the release and activation of Nrf2 [58]. A redox independent cross-talk also exists between the Nrf2-Keap 1 axis and autophagy through p62, an autophagy adaptor protein. p62 activates Nrf2 by a noncanonical pathway. p62 binds to Keap 1, the inhibitor of Nrf2, and induces Keap 1 degradation by autophagy [56]. Intermittent activation of $\mathrm{Nrf2}$ through the canonical pathway confers cellular protection and functional integrity whereas prolonged activation of $\mathrm{Nrf2}$ through the noncanonical pathway appears to be detrimental, resulting in tissue injuries and inflammation [49]. In acute lung injury, autophagy is induced by different stimuli including the oxidative stress [57]. However, the role of autophagy in acute lung injury still remains controversial depending on the underlying cause of the lung injury, on the cell types, and on the stage of lung injury. mTOR inhibition may be protective.

\section{Complexity of the anti-oxidant response}

It is clear that Nrf2 is only one mechanism of the antioxidant stress and that multiple products can act on the anti-oxidant stress of COVID-19. As an example, sulforaphane protects against acetaminophen-induced hepatotoxicity [59]. Its anti-oxidant and anti-inflammatory activity may be enhanced in vitro by combining it with some medications used in COVID-19 such as acetaminophen [60]. Moreover, other mechanisms such as lipid rafts, autophagy, the fatty acid transporter CD36 and adipokines may play an equally important role.

\section{Nrf2-interacting nutrients and COVID-19 Interactions with COVID-19}

Obesity, possibly hypertension, type 2 diabetes (T2D) and ageing all represent risk factors for severe COVID19 associated with cytokine storm and IL-6, endothelial damage in different organs and lung damage.

IR is a pathological condition in which cells fail to respond normally to the hormone insulin. Major mechanisms of IR include oxidative stress, inflammation, insulin receptor mutations, endoplasmic reticulum stress, and mitochondrial dysfunction [61]. In COVID-19, IR can be induced by at least ER stress or the $\mathrm{AT}_{1} \mathrm{R}$ pathways. IR is a key component of the metabolic syndrome, a clustering of at least three of the five following medical conditions: abdominal obesity [62], high blood pressure [63], high blood sugar, high serum triglycerides, and low serum high-density lipoprotein (HDL) [64]. The metabolic syndrome is associated with the risk of developing cardiovascular disease and T2D 
Table 2 Effect of Nrf2-interacting nutrients on diseases associated with oxidative stress

\begin{tabular}{|c|c|c|c|c|c|c|c|c|}
\hline & \multicolumn{6}{|l|}{ Insulin resistance } & \multirow[t]{2}{*}{ Lung injury } & \multirow[t]{2}{*}{ IL-6 Cytokines } \\
\hline & $\begin{array}{l}\text { AT1R } \\
\text { down regulation }\end{array}$ & Obesity & HTA & T2D & $\begin{array}{l}\text { Endothelium } \\
\text { damage }\end{array}$ & Ageing & & \\
\hline Berberine & & {$[161,162]$} & [162] & {$[162,173,174]$} & [175] & [176] & [173] & [173] \\
\hline Curcumin & [105] & {$[163,164]$} & [177] & {$[178]$} & [179] & [180] & {$[181,182]$} & [183] \\
\hline EGCG & [106] & [164] & [184] & [185] & [184] & [180] & {$[186,187]$} & [188] \\
\hline Genistein & {$[107,108]$} & [165] & [189] & [190] & [189] & [180] & [191] & [192] \\
\hline Lactobacillus & & {$[168,169]$} & [193] & [194] & [195] & [196] & [197] & [198] \\
\hline Quercetin & & [163] & [199] & [200] & [184] & [180] & [201] & [202] \\
\hline Resveratrol & [109] & {$[163,164]$} & [203] & [204] & [205] & [180] & [206] & [207] \\
\hline Sulforaphane & & {$[170]$} & [208] & [208] & [209] & [180] & [210] & [211] \\
\hline
\end{tabular}

EGCG: Epigallocatechin gallate

Search strategy: For this table, in order to compare the mechanisms of action and properties of Nrf2-interacting nutrients, a PubMed search was initiated. This was not a systematic review, but an attempt to assess whether the impact on the disease has been described

We searched PubMed using the display option "best matches"

We first searched "systematic reviews" by PubMed for the different nutrients and we collected the first "best match" systematic review related to the question

If there was no systematic review, we searched for "reviews" and we collected the first "best match" review related to the question

If there was no review, we searched for papers and we collected the first "best match" paper related to the question

Table 3 Mechanisms involved in the antioxidant effects of Nrf2-interacting nutrients

\begin{tabular}{|c|c|c|c|c|c|c|}
\hline & Nrf2 & mTOR & PPARY & NFKB & ERK & elF2a \\
\hline Effect & Activation & Inhibition & Activation & Inhibition & Activation & Inhibition \\
\hline Berberine & [173] & [176] & [212] & {$[71]$} & {$[176]$} & [87] \\
\hline Curcumin & {$[180,213]$} & {$[213,214]$} & [213] & [213] & [213] & [88] \\
\hline EGCG & [180] & [214] & [215] & {$[216,217]$} & [217] & [90] \\
\hline Genistein & [180] & [218] & [219] & [220] [221] & [222] & [91] \\
\hline Lactobacillus & [223] & [224] & [225] & [223] & [226] & \\
\hline Quercetin & [180] & [227] & [219] & [228] & [229] & [92] \\
\hline Resveratrol & [180] & {$[214,230]$} & [219] & [220] & [109] & [93] \\
\hline Sulforaphane & [180] & {$[98,231]$} & [208] & [208] & [232] & [233] \\
\hline
\end{tabular}

EGCG: Epigallocatechin gallate

The search strategy used in Table 2 was applied in an attempt to assess whether a mechanism of action could be identified

$[65,66]$. All nine Nrf2-interacting nutrients had some effect-although sometimes weak-against obesity, hypertension and T2D (Table 2).

IR is frequently associated with endothelial dysfunction and has been proposed to play a major role in cardiovascular [67], kidney [68] or cerebrovascular diseases [69]. All nine Nrf2-interacting nutrients had an effect against endothelial damage.

Ageing is associated with IR [70] and all nine Nrf2interacting nutrients had an effect on ageing. All nine Nrf2-interacting nutrients reduce IL- 6 and cytokines.

Most Nrf2-interacting nutrients have an action on mTOR, PPAR $\gamma, \mathrm{NF \kappa B}$, ERK and eIF2 $\alpha$ (Table 3 ).
Table 4 Antiviral effects of Nrf2-interacting nutrients

\begin{tabular}{llll}
\hline & Antiviral & COVID & STING \\
\hline Berberine & {$[71]$} & {$[71]$} & \\
Curcumin & {$[72]$} & {$[234-237]$} & \\
EGCG & {$[238]$} & {$[239-242]$} & {$[243]$} \\
Genistein & {$[244]$} & {$[245]$} & \\
Lactobacillus & {$[246]$} & {$[246,247]$} & \\
Quercetin & {$[248]$} & {$[249-253]$} & \\
Resveratrol & {$[254]$} & {$[255-259]$} & \\
Sulforaphane & {$[260]$} & & {$[84]$} \\
\hline
\end{tabular}

The search strategy used in Table 2 was applied in an attempt to assess whether anti-viral or anti-COVID properties have been described 


\section{Anti-viral effects}

Nrf2-interacting nutrients have large antiviral activities demonstrated in humans and animals (Table 4).

Berberine through NFKB and MAPK pathways has an anti-viral activity on several viruses, and potentially against SARS-CoV-2 [71]. Curcumin can block the entry of viruses into cells or its replication in the cell [72]. It acts on NFKB [73] or MAPK [74]. EGCG has multiple antiviral properties possibly though MAPK [75].

The suppressive effects of EGCG on viral replication were abolished in cells with knocked-down Nrf2 expression [76]. siRNA-mediated depletion of Nrf2 boosted HIV infectivity in primary macrophages and reduced the anti-viral effects of sulforaphane [77]. In a murine model, RSV-induced bronchopulmonary inflammation, epithelial injury, and mucus cell metaplasia as well as nasal epithelial injury were significantly greater in $\mathrm{Nrf2}(-/-)$ mice than in $\mathrm{Nrf} 2(+/+)$ mice. Sulforaphane pre-treatment significantly limited lung RSV replication and virusinduced inflammation in $\mathrm{Nrf} 2(+/+)$ but not in Nrf2(/-) mice. This effect may be mediated though NFKB [78]. Sulforaphane through Nrf2 significantly suppressed the hepatitis $\mathrm{C}$ virus $(\mathrm{HCV})$ protein and RNA levels in $\mathrm{HCV}$ replicon cells and infectious system [79]. Caffeic acid could modulate Keap1/Nrf2 interaction via increasing p62 expression, leading to the stabilization of Nrf2 and $\mathrm{HO}-1$ induction, and an elicit IFN $\alpha$ antiviral response to suppress HCV replication [80]. HCV genome replication was also suppressed in HCV sub-genomic replicon-bearing cells by bardoxolone methyl (BARD), an Nrf2 activator [81].

Type I IFNs (IFN $\alpha$ and - $\beta$ ) are central to immune-protection against viral infection [82]. A balanced production of type I IFNs is needed for the protection against virus, but excessive production is a potent driver of pathology [82]. Intracellular DNA and RNA sensors are essential in the innate immune response to viruses, causing the secretion of type I IFNs, cytokines and chemokines from infected cells. Viral cytosolic DNA is recognized by DNA sensors such as cyclic GMP-AMP synthase (cGAS) and its downstream signalling effector stimulator of interferon genes (STING) [83]. Sulforaphane through Nrf2 activation decreases STING expression and responsiveness to STING agonists while increasing susceptibility to infection with DNA viruses [84]. Reduction of STING expression by Nrf2 is mechanistically distinct from how Nrf2 reduces the release of the pro-inflammatory cytokines IL-1 $\beta$ and IL-6 [84]. Nrf2 negatively regulates Type I INF responses and increases susceptibility to herpes genital infection in mice [85]. Itaconate is a crucial anti-inflammatory metabolite that acts via Nrf2 to limit inflammation and modulate type I IFNs [86].

\section{mTOR and eIF $2 a$}

Several Nrf2-interacting nutrients act through mTOR or eIF $2 \alpha$. The insulin-sensitizing action of berberine was related to reducing ER stress in Hep G2 cells. The levels of phosphorylation both on PERK and eIF2 $\alpha$ were inhibited in cells pretreated with berberine [87]. In an IR animal model, curcumin was found to act on eIF2 $\alpha$ [88]. The induction of the ER stress pathway by green tea EGCG in colorectal cancer cells is mediated by the activation of PERK [89]. The proteasome inhibitors Bortezomib (BZM) and MG132 trigger cancer cell death via induction of ER stress and UPR. EGCG antagonizes BZM toxicity by exacerbating the activation of autophagy and eIF $2 \alpha$ up-regulation [90]. In rats, genistein protects against acute pancreatitis via the activation of an apoptotic pathway mediated through activation of multiple ER stress-related regulators like GRP78, PERK, and eIF2 $\alpha$ [91]. Quercetin blocks airway epithelial cell chemokine expression though eIF2 $\alpha$ phosphorylation [92]. Pterostilbene (PT), a natural analogue of resveratrol, inhibits hepatocellular cell (HCC) growth without the induction of apoptosis in an ER stress- and autophagy-dependent manner through the eIF $2 \alpha$ pathway [93]. Resveratrol modulates response against acute inflammatory stimuli in aged mouse brain. ER stress markers demonstrated significant changes in resveratrol-treated mice after LPS treatment, specifically in eIF $2 \alpha$ [94]. Other studies have found an effect of resveratrol on eIF2 $\alpha[95,96]$.

Sulforaphane exerts a neuroprotective effect involving Nrf2-dependent reductions in oxidative stress, mTORdependent inhibition of neuronal apoptosis, and the restoration of normal autophagy [97]. Sulforaphane also inhibits mTOR in an Nrf2-independent manner [98].

Kimchi attenuates fatty streak formation in the aorta of low-density lipoprotein receptor knockout mice via the inhibition of ER stress (via several mechanisms including eIF2 $\alpha$ ) and apoptosis [99]. Nutrients originating from Kimchi and its ingredients modulate the Nrf2/PERK signalling pathway to homeostasis in oxidative stress states. Kimchi and its bioactive compound ((3-4'-hydroxyl3',5'-dimethoxyphenyl) propionic acid: HDMPPA), which is a metabolite result from fermentation, alleviate oxidative stress and inflammatory response not only via the Nrf2 pathway, but also via the PERK/CHOP pathway, which induced apoptosis of ER, in cardiovascular disease and ageing models [100-102]. In addition, Arvelexin from Brassica rapa and anthocyanin-rich extract from red cabbage exert anti-inflammatory properties by the inhibition of NF- $\mathrm{\kappa B}$ activation and by Nrf2-regulated HO-1 induction in macrophages and apolipoprotein E-deficient mice [103, 104], suggesting that Nrf2 activation during inflammation antagonizes the NF- $k B$ pathway. It is possible that the intake of Kimchi may help to 
mitigate COVID-19 outcomes by maintaining or restoring the Nrf2 system.

$A T_{1} R$ Curcumin [105], EGCG [106], genistein [107, 108] and resveratrol [109] impact the $\mathrm{AT}_{1} \mathrm{R}$ pathway. $\mathrm{NADPH}$ oxidases of the Nox family are important sources of ROS and important agents in hypertension. They increase blood pressure in the presence of Ang II, an important and potent regulator of cardiovascular NADPH oxidase, via $A_{1} R$. Several natural compounds such as berberine, curcumin, quercitine, resveratrol and others are Nox inhibitors [110]. Dietary curcumin supplementation can increase antioxidant activity through the induction of heme oxygenase- 1 , a scavenger of free radicals, and through the reduction of reactive oxygen species and Nox-2 [111]. Sulforaphane reduces Ang II-induced vascular smooth muscle cells through Nrf2 signalling [112].

\section{mTOR and autophagy}

The autophagic process is initiated by inactivation of the mechanistic/mammalian target of rapamycin (mTOR), the major autophagy suppressor [52]. The role of mTOR is unclear in coronavirus infection [52]. Nrf2 can directly regulate mTOR [113]. Certain mTOR or Rac1 inhibitors derived from rapamycin and azathioprine activate autophagy [51]. mTOR inhibitors were proposed to be tested in COVID-19 [114]. Many Nrf2-interacting nutrients are mTOR inhibitors and might have a role in autophagy.

\section{TRPA1 and TRPV1}

Several Nrf2-interacting nutrients are direct TRPA1 (transient receptor potential ankyrin 1) [115] or TRPV1 (transient receptor potential vanilloid 1) activators. TRPA1 induces inflammation, plays key roles in the physiology of almost all organs and exhibits a high sensitivity of TRPs to oxidants. It is involved in many COVID19 symptoms. TRPA1 can be activated by many foods (Table 5). There is a substantial overlapping of electrophilic ligands between TRPA1 and Nrf2. It has been suggested that the two systems might be part of the same network, with TRPA1 representing the sensory arm, and Nrf2 its biochemical counterpart [115]. However, not all Nrf2-interacting nutrients are activators of TRPA1 and mustard oil, the first TRPA1 agonist found [116], does not interact with Nrf2.

In COVID-19, some Nrf2-interacting nutrients may act by desensitizing TRPA1 (and possibly TRPV1) receptors (Bousquet et al. in preparation).
Table 5 TRPA1 and TRPV1 interactions of Nrf2-interacting nutrients

\begin{tabular}{lll}
\hline & TRPA1 & TRPV1 \\
\hline $\begin{array}{ll}\text { Berberine } \\
\text { Curcumin }\end{array}$ & Antagonist [262] & Antagonist [261] \\
EGCG & Agonist [263] & Antagonist [262] \\
Genistein & Antagonist [265] & Antagonist [264] \\
Lactobacillus & & Antagonist [266] \\
Quercetin & Agonist [267] & Antagonist \\
Resveratrol & Antagonist [269, 270] & Antagonist [268] \\
Wasabi & Agonist [272] & Antagonist [271] \\
Capsaicin & Agonist [273] & Agonist [272] \\
\hline
\end{tabular}

The search strategy used in Table 2 was applied in an attempt to assess whether a mechanism of action could be identified

\section{Complex interactions in oxidative stress}

IR induces oxidative stress either through the overproduction of superoxide by ER stress or the activation of Ang II-mediated upregulation of nicotinamide adenine dinucleotide phosphate (NADPH)-oxidase (NOX) activity, resulting in the cytosolic production of ROS [117] (Fig. 2).

One of the key features of the complex interaction between nutrients and the oxidative stress/inflammatory response is the differential regulation of $\mathrm{NFKB}_{\mathrm{K}}$ and Nrf2 by the cell redox status [118]. Nrf2 and NFkb are present in an inactive form in the cytosol since they are linked to an inhibitory compound iNFkB or INrf2 (Keap 1 ), both targets of reactive oxygen species [119-121]. In the case of a large production of ROS, which would overwhelm the antioxidant defence, $\mathrm{iNF} B \mathrm{~B}$ is oxidized and catabolized. Furthermore, NFKB is translocated to the nucleus and initiates the expression of inflammatory proteins such as cytokines, chemokines, adhesion molecules, cytokine receptors, iNO synthases, lipoxygenases, cyclooxygenases and growth factors [122, 123]. Once produced, cytokines are able to activate oxidant production by the NADPH oxidase complex, leading to an oxidative burst, which could in turn enhance NFKB activation. Thus, $\mathrm{NF \kappa B}$ activation results in a directional and synergistic linkage of inflammation and oxidative stress [120, 124].

The canonical pathway of Nrf2 activation also involves changes in the cell redox state [189]. A weak or controlled ROS production results in the degradation of Keap 1. Thus, Nrf-2 could be translocated to the nucleus, binds to the antioxidant response element and activates an antioxidant enzyme such as Heme Oxigenase, SOD and catalase or cytoprotective genes $[125,126]$. It could also reduce the production of ROS [127]. The increase in antioxidant defence maintains or restores the cellular 


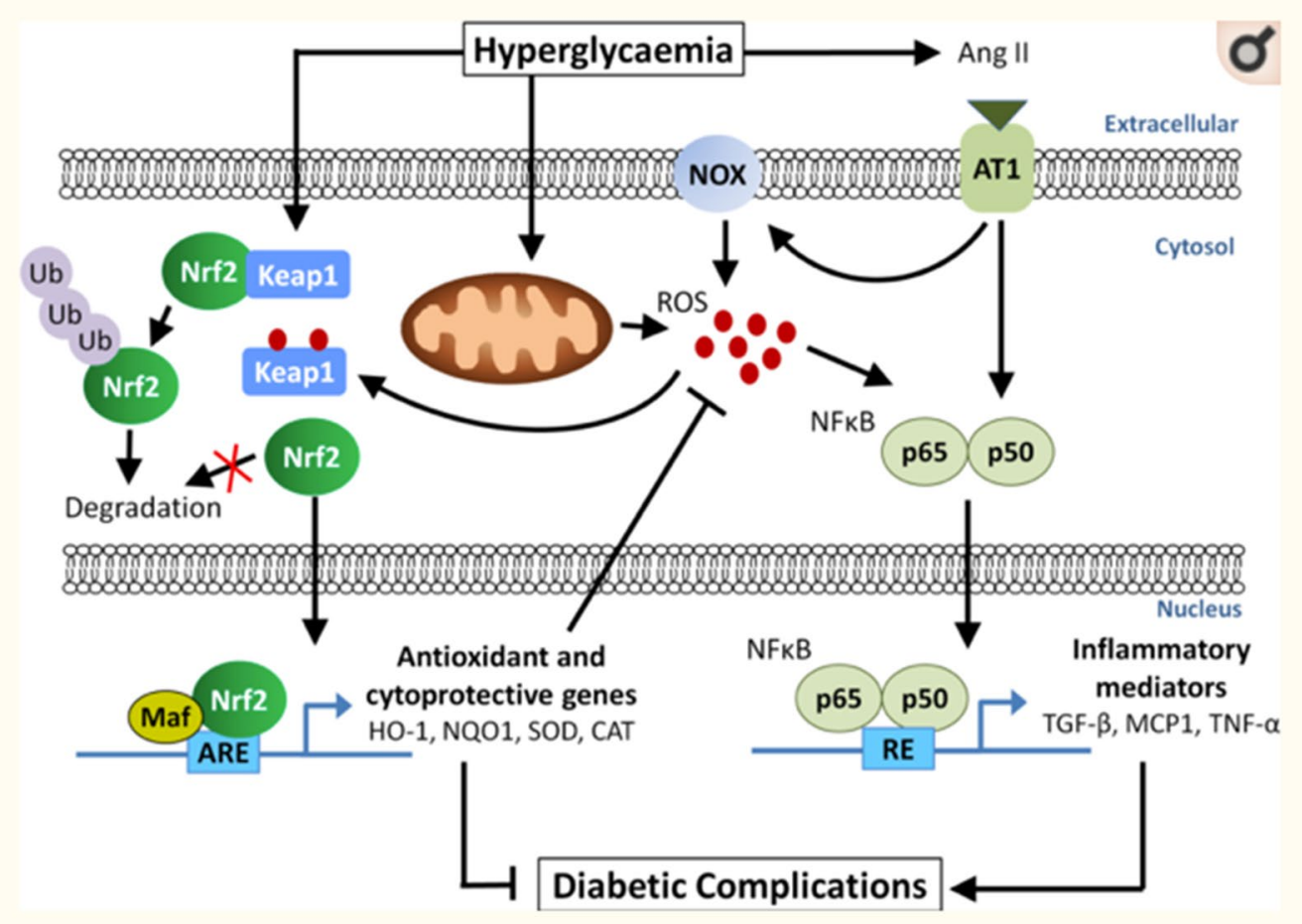

Fig. 2 Complex interactions leading to oxidative stress in diabetes (from [117])

redox state. In addition, Nrf2 stimulation could downregulate NFkB activation [128, 129]. In fact, redox signalling appears as a black box, controlling both $\mathrm{NrF} 2$ and $\mathrm{Nf}$ B B activation and thus regulating inflammation and reparation. It is now recognized that the regulation of both pathways, $\mathrm{Nf} \kappa \mathrm{B}$ and $\mathrm{Nrf} 2$, in part linked to the redox status, involved a cross talk to bring a coordinated inflammatory response $[130,131]$. The intensity of the ROS insult could be a key factor in the imbalance of the NFkB/Nrf2 system [132]. In the case of oxidative stress, stimulation of $\mathrm{NF}_{\mathrm{K}} \mathrm{B}$ (associated with a degradation of both Keap 1 and Nrf2) results in an amplification loop of inflammation. Thus, an imbalance between the NFKB and Nrf2 pathways has already been observed in T2D [112] or in multiple sclerosis. By contrast, an active and effective anti-oxidant system could result in a preventive loop leading to anti-oxidative and anti-inflammatory response. In this context, a positive modulation of Nrf2 by nutrients could act as an «oxidative pre-conditioning» system, and the resulting increase in the antioxidant enzyme could attenuate ROS deleterious effects and maintain cell integrity $[133,134]$.

This black box redox system could be effective in respiratory infection, particularly in COVID-19 [122]. Indeed, COVID-19 activates RAAS and induces ER stress, resulting in ROS production [32, 33], which could be further enhanced by risk factors such as obesity, diabetes, and hypertension [135-137]. Interestingly, RAAS activation seems related to COVID infection severity [41]. If the ROS production overwhelms antioxidant defence, a vicious circle linking oxidative stress and inflammation is initiated leading to a cytokine storm, as well as lung and endothelial injury. On the other hand, if Nrf2 is activated via nutrients, the antioxidant response could maintain or restore an adequate redox status. This would lead to an antioxidant and anti-inflammatory response resulting in a pauci-symptomatic infection. Interestingly, very recently, a similar effect on the $\mathrm{Nrf} 2$ / $\mathrm{NfkB}$ balance via redox signalling was hypothesized via ozone therapy [138].

However, although the therapeutic potential of Nrf2 raised great hopes in the early 2010s [139], Nrf2 levels vary significantly depending on the physiological and pathological context. Thus, a properly timed and targeted manipulation of the Nrf2 pathway is critical for an effective treatment [140]. Surprisingly, only one Nrf2based treatment has been approved: dimethyl fumarate [141], not devoid of side effects [142, 143]. This suggests that the balance is difficult to reach in drug development. Nrf2 overexpression may also be associated with 
diabetic nephropathy or retinopathy [117]. Recently, well-designed clinical trials with bardoxolone, an Nrf2 antagonist, were cancelled or stopped due to safety concerns [144]. The Nrf2 system plays an important role in the body's natural defence against hyperglycaemiainduced damage. However, this initial adaptive response to counteract the diabetes-driven oxidative stress appears to be short-lived, after which the Nrf2 system becomes overwhelmed under chronic glucose stimulation [117].

\section{Obesity, diet, Nrf2 and COVID-19}

In general, T2D and obesity prevalence are associated and the following has been stated by the NCD Risk Factor Collaboration (NCD-RisC) "The upsurge of T2D reflects the global obesity epidemic" [145]. However, many countries in Sub-Saharan Africa or Eastern Asia have a very low obesity prevalence that is not necessarily associated with a low diabetes prevalence (Fig. 3). These countries have the lowest obesity prevalence as well as the lowest COVID-19 death rates. Obesity is lower in Canada than in the US and this may partly explain differences in COVID-19 severity between these two countries. Obesity is high in South Africa, possibly explaining the higher

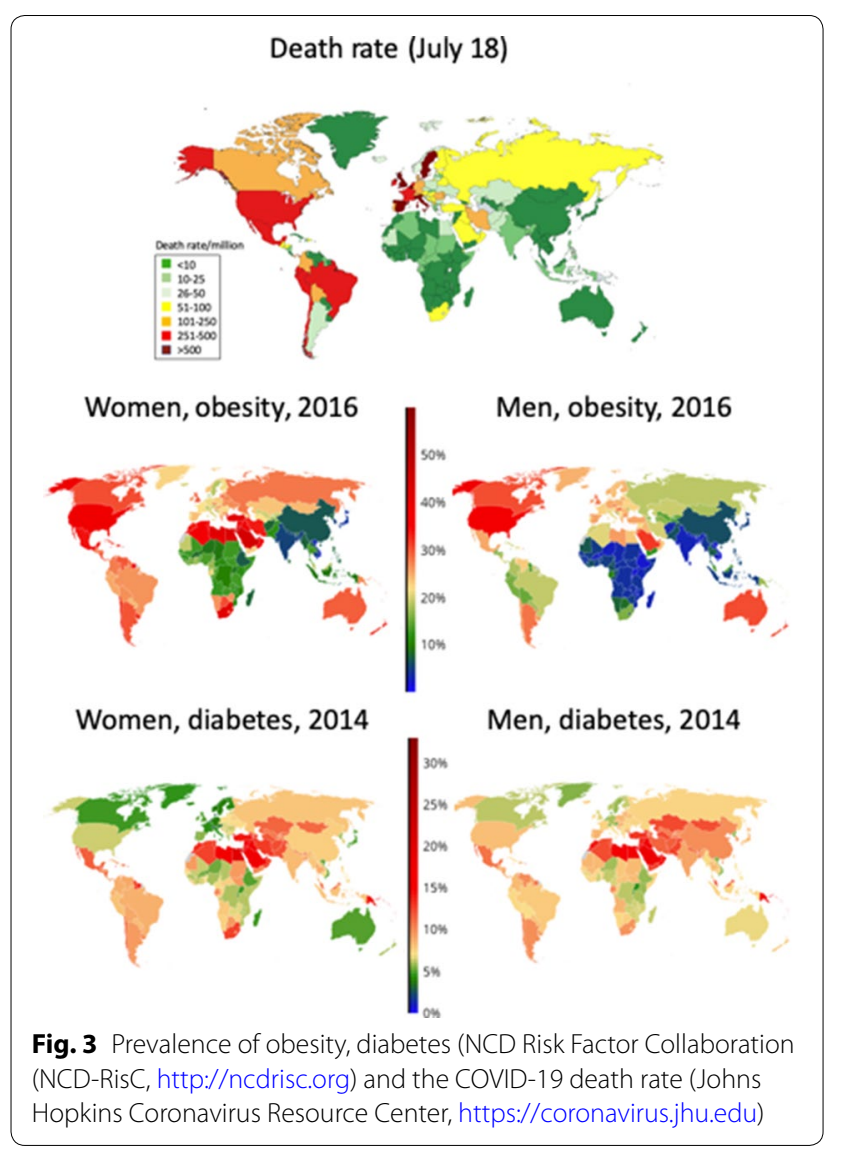

death rate in this country than in other Sub-Saharan African countries.

Many factors can explain this diabetes/obesity paradox. Genetic differences between countries are clear. However, the RODAM (Research on Obesity \& Diabetes among African Migrants) study used a unique approach of comparing Ghanaians resident in the Netherlands, Germany, UK and Ghana to unravel the causes of obesity and T2D among African migrants and non-migrants. It showed striking differences suggesting that environmental factors are of great importance. Globally, one in 10 individuals is affected by T2D. In migrants, there is a higher T2D prevalence, the age of onset is younger and complications are more severe. One of the main determinants of T2D is obesity, which also disproportionally affects migrants [146-149]. In rural Ghanaians, most T2D is independent of obesity [150] (Fig. 4). Differences in food preferences were found across study sites: (i) in rural Ghana, diet concentrated on starchy foods ("roots, tubers, and plantain" diet) including cassava, (ii) in urban Ghana, nutrition was dominated by animal-based products, and (iii) in Europe, diet was highly diverse [151]. The "roots, tubers, and plantain" diet was directly associated with increased 10-year cardiovascular disease risk [152] but the relationship between diet and T2D was unclear [153]. In the national Korean cohort, obesity (50.4\%) and abdominal obesity (47.8\%) are associated with diabetes [154].

In COVID-19, obesity is a more severe risk factor than T2D [155]. There is a dose-dependent association of obesity with worse COVID-19 morbidity requiring hospitalization and intensive care and with mortality. This particularly applies to patients younger than 50 to 60 years of age [156]. Obesity is an important independent risk factor for serious COVID-19 disease [157, 158]. The association between BMI and COVID-19-related

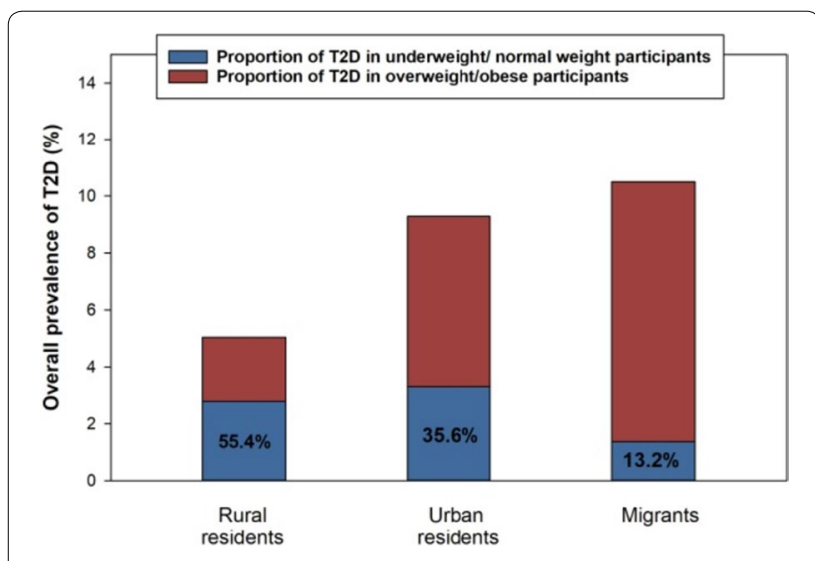

Fig. 4 Links between obesity and diabetes in Ghanaians [150] 


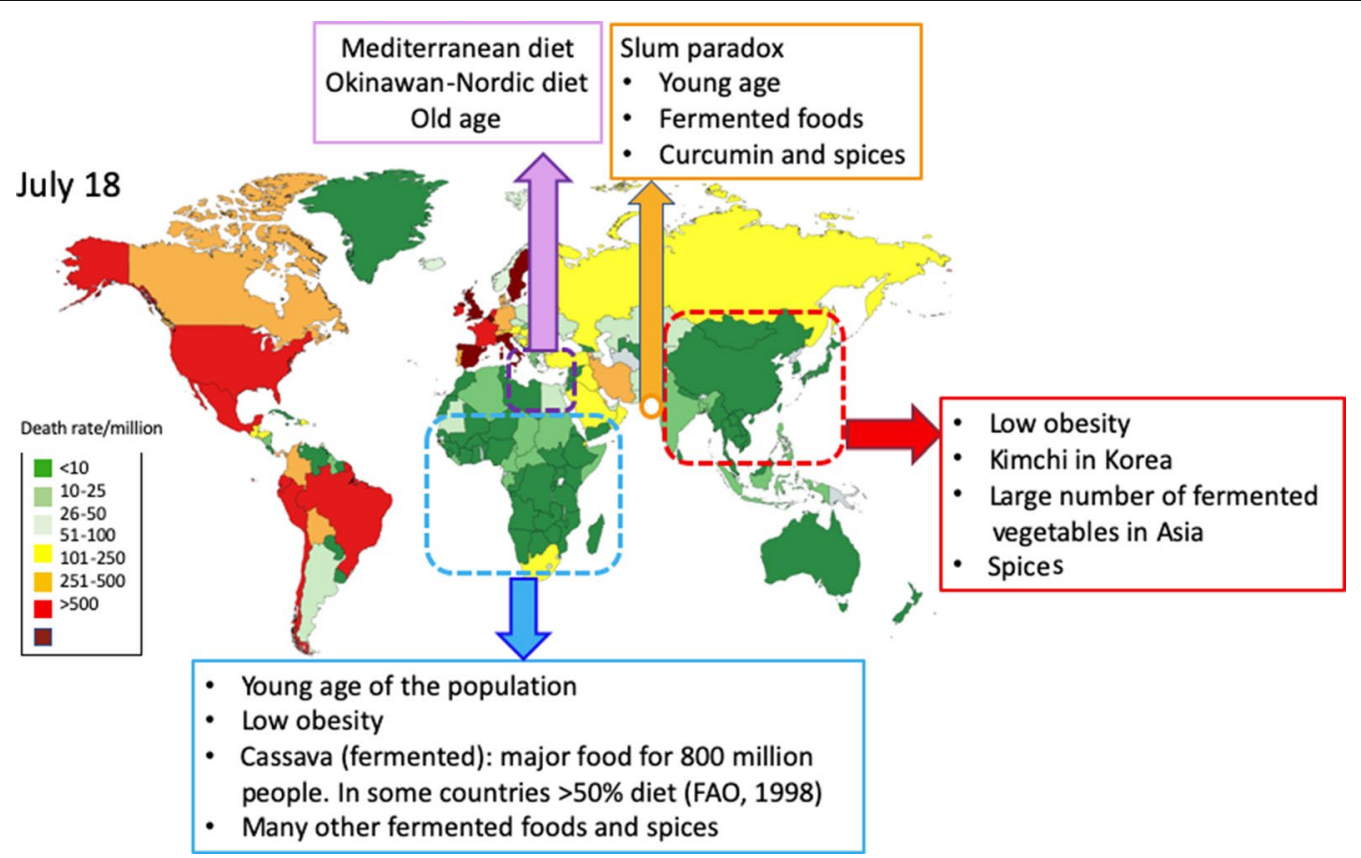

Fig. 5 Geographic differences in COVID-19 death rates (Johns Hopkins Coronavirus center) and diet possibly explaining these differences

mortality was U-shaped, both in type 1 diabetes and in T2D (lowest risk for those with a BMI of $25 \cdot 0-29.9 \mathrm{~kg} /$ $\mathrm{m}^{2}$ ) [159]. These data suggest differences between these two features of the metabolic syndrome for COVID-19 severity.

Nrf2 is also involved in complications of Type- 1 diabetes [160]. All nine Nrf2-interacting nutrients had an effect against obesity, often through IR [161-170] (Table 2). In addition, Nrf2 may improve adipogenesis and adipocyte differentiation [171]. Thus, diet may be important in the prevention/management of obesity and, at the same time, may reduce the impact of COVID- 19 .

\section{Conclusions}

Interestingly, all nutrients tested had a similar effect on IR, cytokine storm, lung injury and endothelial damage. They were all active on most of the tested Nrf2 pathways. These data strongly suggest a common mechanism of action for all nutrients. These effects appear to be highly conserved [172]. However, we need to understand the differences between obesity and T2D in some countries with low obesity prevalence. These mechanisms may help to better appraise the potential severity of COVID-19 (Fig. 5).

It is tempting to propose that Nrf2-interacting foods and nutrients can help re-balance IR, and that they can have a significant effect on COVID-19 severity, and possibly also on susceptibility to infection by SARS-CoV-2. It is therefore possible that an increasing intake of specific foods may achieve an optimal natural balance for the Nrf2 pathway, since COVID-19 death rates, used as a proxy of severity, are low or very low in some countries where Nrf2-interacting nutrients are largely used (Fig. 5). Understanding the balance between Nrf2-interacting foods and nutrients would help to: (i) better understand the mechanisms of the oxidative stress in the IR diseases, (ii) develop optimal Nrf2-interacting nutrients and diets to reduce the prevalence and severity of IR diseases, (iii) optimize Nrf2 drug development and (iv) develop these strategies to mitigate COVID-19 severity.

There are still many unresolved questions requesting research on the time of onset of any efficacy of foods in COVID-19, the amount of the food to be administered and the interactions with the microbiome.

\section{Abbreviations}

ACE: Angiotensin converting enzyme; AKT: Protein kinase B Ang II: Angiotensin II; AT R: Angiotensin II receptor type 1; COVID-19: Coronavirus 19 disease; DNA: Desoxyribonucleic acid; EGCG: Epigallocatechin gallate; elF2a: Elongation initiation factor 2a; ER: Endoplasmic reticulum; ERK: Extracellular signalregulated kinases; GI: Gastro-intestinal; HCV: Hepatitis C virus; HIV: Human immunodeficiency virus; IFN: Interferon; IR: Insulin resistance; Keap 1: Kelch-like ECH-associated protein 1; LAB: Lactic acid bacilli; mTOR: Mammalian target of rapamycin; mTORC: MTOR complex; MAPK: Mitogen-activated protein kinases; NADPH: Nicotinamide adenine dinucleotide phosphate; NF-KB: Nuclear factor kappa B; Nox: NADPH oxydase; Nrf2: Nuclear factor (erythroid-derived 2)-like 2; PI3K: Phosphoinositide 3-kinase; PPAR: Peroxisome proliferator-activated receptor; PERK: Protein kinase R (PKR)-like endoplasmic reticulum kinase; PKR: Protein kinase R; RAAS: Renin-Angiotensin-Aldosterone system; ROS: Reactive oxygen species; RSV: Respiratory syncytial virus; SARS: Severe acute respiratory syndrome; SARS-Cov-2: Severe acute respiratory syndrome coronavirus 2; STING: Signalling effector stimulator of interferon genes; TRPA1: Transient receptor potential ankyrin 1; TRPV1:Transient receptor potential vanillin 1;T2D: Type 2 diabetes; UPR: Unfolded protein response. 


\section{Acknowledgements}

ARIA group: Amir Hamzah Abdul Latiff, Baharudin Abdullah, Werner Aberer, Nancy Abusada, Ian Adcock, Alejandro Afani, Ioana Agache, Xenofon Aggelidis, Jenifer Agustin, Cezmi A Akdis, Mübeccel Akdis, Mona Al-Ahmad, Abou Al-Zahab Bassam, Hussam Alburdan, Oscar Aldrey-Palacios, Emilio Alvarez Cuesta, Hiba Alwan Salman, Ashraf Alzaabi, Salma Amade, Gene Ambrocio, Rosana Angles, Isabella Annesi-Maesano, Ignacio J Ansotegui, Josep M. Anto, Paula Ara Bardajo, Stefania Arasi, Margarete Arrais, Hasan Arshad, Maria-Cristina Artesani, Estrella Asayag, Francesca Avolio, Khuzama Azhari, Claus Bachert, Diego Bagnasco, llaria Baiardini, Nissera Bajrović, Petros Bakakos, Sergio Bakeyala Mongono, Christine Balotro-Torres, Sergio Barba, Cristina Barbara, Elsa Barbosa, Bruno Barreto, Joan Bartra, Xavier Basagana, Eric D. Bateman, Lkhagvaa Battur, Anna Bedbrook, Martín Bedolla Barajas, Bianca Beghé, Antra Bekere, Elizabeth Bel, Ali Ben Kheder, Mikael Benson, ElenaCamelia Berghea, Karl-Christian Bergmann, Roberto Bernardini, David Bernstein, Mike Bewick, Slawomir Bialek, Artur Białoszewski, Thomas Bieber, Nils E. Billo, Maria-Beatrice Bilo, Carsten Bindslev-Jensen, Leif Bjermer, Hubert Blain, Irina Bobolea, Malgorzata Bochenska Marciniak, Christine Bond, Attilio Boner, Matteo Bonini, Sergio Bonini, Sinthia Bosnic-Anticevich, Isabelle Bosse, Sofia Botskariova, Jacques Bouchard, Louis-Philippe Boulet, Rodolphe Bourret, Philippe Bousquet, Fulvio Braido, Andrew Briggs, Christopher E Brightling, Jan Brozek, Luisa Brussino, Roland Buhl, Roxana Bumbacea, Rosalva Buquicchio, María-Teresa Burguete Cabañas, Andrew Bush, William W Busse, Jeroen Buters, Fernan Caballero-Fonseca, Moïses A Calderon, Mario Calvo, Paulo Camargos, Thierry Camuzat, FR Canevari, Antonio Cano, G Walter Canonica, Arnaldo Capriles-Hulett, Luis Caraballo, Vicky Cardona, Kai-Hakon Carlsen, Jonas Carmona Pirez, Jorge Caro, Warner Carr, Pedro Carreiro-Martins, Fredelita Carreon-Asuncion, Ana-Maria Carriazo, Carme Carrion y Ribas, Thomas Casale, Mary-Ann Castor, Elizabeth Castro, A.G. Caviglia, Lorenzo Cecchi, Alfonso Cepeda Sarabia, Maciej Chalubinski, Ramanathan Chandrasekharan, Yoon-Seok Chang, Victoria Chato-Andeza, Lida Chatzi, Christina Chatzidaki, Niels H. Chavannes, Claudia Chaves Loureiro, Aurora-Alejandra Chavez Garcia, Marta Chelninska, Yuzhi Chen, Lei Cheng, Sharon Chinthrajah, Tomas Chivato, Ekaterine Chkhartishvili, George Christoff, Henry Chrystyn, Derek K Chu, Antonio Chua, Alexander Chuchalin, Kian Fan Chung, Alberto Cicerán, Cemal Cingi, Giorgio Ciprandi, leva Cirule, Ana-Carla Coelho, Enrico Compalati, Jannis Constantinidis, Jaime Correia de Sousa, Elisio Manuel Costa, David Costa, María del Carmen Costa Domínguez, André Coste, M. Cottini, Linda Cox, Carlos Crisci, Maria Angiola Crivellaro, Alvaro A Cruz, John Cullen, Adnan Custovic, Biljana Cvetkovski, Wienczyslawa Czarlewski, Gennaro D’Amato, Jane da Silva, Ronald Dahl, Sven-Erik Dahlen, Vasilis Daniilidis, Louei Darjazini Nahhas, Ulf Darsow, Janet Davies, Frédéric de Blay, Giulia De Feo, Eloisa De Guia, José-Ricardo de la Torre Navarrete, Chato de los Santos, Esteban De Manuel Keenoy, Govert De Vries, Diana Deleanu, Pascal Demoly, Judah Denburg, Philippe Devillier, Alain Didier, Sanja Dimic Janjic, Maria Dimou, Anh Tuan Dinh-Xuan, Ratko Djukanovic, Maria Do Ceu Texeira, Dejan Dokic, Margarita Gabriela Domínguez Silva, Habib Douagui, Nikolaos Douladiris, Maria Doulaptsi, Gérard Dray, Ruta Dubakiene, Eve Dupas, Stephen Durham, Marzia Duse, Mark Dykewicz, Didier Ebo, Natalija Edelbaher, Thomas Eiwegger, Patrik Eklund, Yehia El-Gamal, Zeinab A. El-Sayed, Shereen S. El-Sayed, Magda El-Seify, Regina Emuzyte, Lourdes Enecilla, Marina Erhola, Heidilita Espinoza, Jesús Guillermo Espinoza Contreras, John Farrell, Lenora Fernandez, Paola Fimbres Jimenez, Antje Fink Wagner, Alessandro Fiocchi, Wytske J Fokkens, Lenia Folletti, Joao A Fonseca, Jean-François Fontaine, Francesco Forastiere, Jose Miguel Fuentes Pèrez, Emily Gaerlan-Resureccion, Mina Gaga, José Luis Gálvez Romero, Amiran Gamkrelidze, Alexis Garcia, Cecilia Yvonne García Cobas, María de la Luz Hortensia García Cruz, Valeria Garcia Ortiz, Jacques Gayraud, Matteo Gelardi, Bilun Gemicioglu, Dimitra Gennimata, Sonya Genova, José Gereda, Roy Gerth van Wijk, Antonio Giuliano, René-Maximiliano Gomez, Miguel-Ange Gonzalez Ballester, Sandra González Diaz, Maia Gotua, Christos Grigoreas, Ineta Grisle, Marta Guidacci, Nick Guldemond, Zdenek Gutter, Antonieta Guzmán, Tari Haahtela, Ramsa Halloum, David Halpin, Eckard Hamelmann, Suleiman Hammadi, Richard Harvey, Enrico Heffler, Joachim Heinrich, Adnan Hejjaoui, Birthe Hellquist-Dahl, Luiana Hernández Velázquez, Mark Hew, Elham Hossny, Peter Howarth, Martin Hrubiško, Yunuen Rocío Huerta Villalobos, Marc Humbert, Salina Husain, Michael Hyland, Guido laccarino, Moustafa Ibrahim, Nataliya Ilina, Maddalena Illario, Cristoforo Incorvaia, Antonio Infantino, Carla Irani, Zhanat Ispayeva, Juan Carlos Ivancevich, Edgardo EJ Jares, Deborah Jarvis, Ewa Jassem, Klemen Jenko, Rubén Darío Jiméneracruz Uscanga, Sebastian L Johnston, Guy Joos, Maja Jošt, Kaja Julge, Ki-Suck Jung, Jocelyne Just, Marek Jutel, Igor Kaidashev, Omer Kalayci, Fuat Kalyoncu, Jeni Kapsali,
Przemyslaw Kardas, Jussi Karjalainen, Carmela A. Kasala, Michael Katotomichelakis, Loreta Kavaliukaite, Kazi S. Bennoor, Thomas Keil, Paul Keith, Musa Khaitov, Nikolai Khaltaev, You-Young Kim, Bruce Kirenga, Jorg Kleine-Tebbe, Ludger Klimek, Fanny W. Ko, Bernard Koffi N'Goran, Evangelia Kompoti, Peter Kopač, Gerard Koppelman, Anja Koren Jeverica, Seppo Koskinen, Mitja Košnik, Tomasz Kostka, Kosta V. Kostov, Marek L Kowalski, Tanya Kralimarkova, Karmen Kramer Vrščaj, Helga Kraxner, Samo Kreft, Vicky Kritikos, Dmitry Kudlay, Mikael Kuitunen, Inger Kull, Piotr Kuna, Maciej Kupczyk, Violeta Kvedariene, Marialena Kyriakakou, Nika Lalek, Massimo Landi, Stephen Lane, Désiree E. LarenasLinnemann, Susanne Lau, Daniel Laune, Jorge Lavrut, Lan Le, Martina Lenzenhuber, Gualtiero Leo, Marcus Lessa, Michael Levin, Jing Li, Philip Lieberman, Giuseppe Liotta, Brian Lipworth, Xuandao Liu, Rommel Lobo, Karin C Lodrup Carlsen, Carlo Lombardi, Renaud Louis, Stelios Loukidis, Olga Lourenço, Jorge A. Luna Pech, Bojan Madjar, Enrico Maggi, Antoine Magnan, Bassam Mahboub, Alpana Mair, Anke-Hilse Maitland van der Zee, Mika Makela, Michael Makris, Hans-Jorgen Malling, Mariana Mandajieva, Patrick Manning, Manolis Manousakis, Pavlos Maragoudakis, Gianluigi Marseglia, Gailen Marshall, Mohammad Reza Masjedi, Jorge F. Máspero, Juan José Matta Campos, Marcus Maurer, Sandra Mavale-Manuel, Cem Meço, Erik Melén, Giovanni Melioli, Elisabete Melo-Gomes, Eli O Meltzer, Enrica Menditto, Andrew Menzies-Gow, Hans Merk, Jean-Pierre Michel, Yann Micheli, Neven Miculinic, Luís Midão, Florin Mihaltan, Nikolaos Mikos, Manlio Milanese, Branislava Milenkovic, Dimitrios Mitsias, Bassem Moalla, Giuliana Moda, María Dolores Mogica Martínez, Yousser Mohammad, Frances-Montserrat Moharra, Mostafa Moin, Mathieu Molimard, Isabelle Momas, Monique Mommers, Alessandro Monaco, Stephen Montefort, Lucia-Elvira Montenegro, Riccardo Monti, Dory Mora, Mario Morais-Almeida, Ralph Mösges, Badr Eldin Mostafa, Joaquim Mullol, Lars Münter, Antonella Muraro, Ruth Murray, Antonio Musarra, Tihomir Mustakov, Robert Naclerio, Kari C. Nadeau, Rachel Nadif, Alla Nakonechna, Leyla Namazova-Baranova, Gretchen Navarro-Locsin, Hugo Neffen, Kristof Nekam, Angelos Neou, Eustachio Nettis, Daniel Neuberger, Laurent Nicod, Stefania Nicola, Verena Niederberger-Leppin, Marek Niedoszytko, Antonio Nieto, Ettore Novellino, Elizabete Nunes, Dieudonné Nyembue, Robyn E. O'Hehir, Cvetanka Odjakova, Ken Ohta, Yoshitaka Okamoto, Kimi Okubo, Brian Oliver, Gabrielle L Onorato, Maria Pia Orru, Solange Ouédraogo, Kampadilemba Ouoba, Francisco-Javier Padilla, Pier Luigi Paggiaro, Aris Pagkalos, Giovanni Pajno, Gianni Pala, SP Palaniappan, Isabella Pali-Schöll, Susanna Palkonen, Stephen Palmer, Carmen Panaitescu Bunu, Petr Panzner, Nikos G Papadopoulos, Vasilis Papanikolaou, Alberto Papi, Bojidar Paralchev, Giannis Paraskevopoulos, Hae-Sim Park, Giovanni Passalacqua, Vincenzo Patella, lan Pavord, Ruby Pawankar, Soren Pedersen, Susete Peleve, Simona Pellegino, Ana Pereira, Mariana Pereira, Tamara Pérez, Andrea Perna, Diego Peroni, Oliver Pfaar, Nhân Pham-Thi, Bernard Pigearias, Isabelle Pin, Konstantina Piskou, Constantinos Pitsios, Davor Plavec, Dagmar Poethig, Wolfgang Pohl, Antonija Poplas Susic, Todor A. Popov, Fabienne Portejoie, Paul Potter, Lars Poulsen, Alexandra Prados-Torres, Fotis Prarros, David Price, Emmanuel Prokopakis, Francesca Puggioni, Elisa Puig-Domenech, Robert Puy, Klaus Rabe, Silvia Rabotti, Filip Raciborski, Josephine Ramos, Cristina Recalcati, Marysia T. Recto, Shereen M. Reda, Frederico S Regateiro, Norbert Reider, Sietze Reitsma, Susana Repka-Ramirez, Erminia Ridolo, Janet Rimmer, Daniela Rivero Yeverino, José Angelo Rizzo, Carlos Robalo-Cordeiro, Graham Roberts, Karen Robles, Nicolas Roche, Mónica Rodríguez González, Eréndira Rodríguez Zagal, Giovanni Rolla, Christine Rolland, Regina Roller-Wirnsberger, Miguel Roman Rodriguez, Antonino Romano, Jan Romantowski, Philippe Rombaux, Joel Romualdez, Jose Rosado-Pinto, Nelson Rosario, Lanny Rosenwasser, Oliviero Rossi, Menachem Rottem, Philip W. Rouadi, Nikoleta Rovina, Irma Rozman Sinur, Mauricio Ruiz, Lucy Tania Ruiz Segura, Dermot Ryan, Hironori Sagara, Daiki Sakai, Daiju Sakurai, Wafaa Saleh, Johanna Salimaki, Konstantinos Samitas, Boleslaw Samolinski, María Guadalupe Sánchez Coronel, Mario SanchezBorges, Jaime Sanchez-Lopez, Melissa Sansonna, Codrut Sarafoleanu, Faradiba Sarquis Serpa, Joaquin Sastre, Eleonora Savi, Agne Savonyte, Bisher Sawaf, Glenis K Scadding, Sophie Scheire, Peter Schmid-Grendelmeier, Juan Francisco Schuhl, Holger Schunemann, Maria Schvalbová, Jorgen Schwarze, Nicola Scichilone, Gianenrico Senna, Cecilia Sepúlveda, Elie Serrano, Sara Shamai, Aziz Sheikh, Mike Shields, VasilShishkov, Nikos Siafakas, Alexander Simeonov, Estelle FER Simons, Juan Carlos Sisul, Brigita Sitkauskiene, Ingelbjorg Skrindo, Tanja Soklič Košak, Dirceu Solé, Martin Sondermann, Talant Sooronbaev, Manuel Soto-Martinez, Manuel Soto-Quiros, Barnaro Sousa Pinto, Milan Sova, Michael Soyka, Krzysztof Specjalski, Annette Sperl, Otto Spranger, Sofia Stamataki, Lina Stefanaki, Cristiana Stellato, Rafael Stelmach, Timo Strandberg, Petra Stute, Abirami Subramaniam, Charlotte Suppli Ulrik, Michael Sutherland, Silvia 
Sylvestre, Aikaterini Syrigou, Luis Taborda Barata, Nadejda Takovska, Rachel Tan Frances Tan, Vincent Tan, Ing Ping Tang, Masami Taniguchi, Line Tannert, Pongsakorn Tantilipikorn, Jessica Tattersall, Filippo Tesi, Uta Thieme, Carel Thijs, Mike Thomas, Teresa To, Ana Maria Todo-Bom, Alkis Togias, Peter-Valentin Tomazic, Vesna Tomic-Spiric, Sanna Toppila-Salmi, Maria-José Torres Jaen, Elina Toskala, Massimo Triggiani, Nadja Triller, Katja Triller, loanna Tsiligianni, M. Uberti, Ruxandra Ulmeanu, Jure Urbancic, Marilyn Urrutia Pereira, Martina Vachova, Felipe Valdés, Rudolf Valenta, Marylin Valentin Rostan, Antonio Valero, Arunas Valiulis, Mina Vallianatou, Erkka Valovirta, Michiel Van Eerd, Eric Van Ganse, Marianne van Hage, Olivier Vandenplas, Tuula Vasankari, Dafina Vassileva, Cesar Velasco Munoz, Maria Teresa Ventura, Cécilia Vera-Munoz, Frédéric Viart, Dilyana Vicheva, Pakit Vichyanond, Petra Vidgren, Giovanni Viegi, Claus Vogelmeier, Leena Von Hertzen, Theodoros Vontetsianos, Dimitris Vourdas, Vu Tran Thien Quan, Martin Wagenmann, Samantha Walker, Dana Wallace, De Yun Wang, Susan Waserman, Katrin Wehner, Magnus Wickman, Sian Williams, Dennis Williams, Nicola Wilson, Gary Wong, Kent Woo, Lucyna Wozniak, John Wright, Piotr Wroczynski, Paraskevi Xepapadaki, Plamen Yakovliev, Masao Yamaguchi, Kwok Yan, Yoke Yeow Yap, Mais Yassin, Barbara Yawn, Panayiotis Yiallouros, Arzu Yorgancioglu, Shigemi Yoshihara, lan Young, Osman B Yusuf, Asghar Zaidi, Fares Zaitoun, Petra Zalud, Heather Zar, M.T. Zedda, Mario E Zernotti, Luo Zhang, Nanshan Zhong, Mihaela Zidarn, Torsten Zuberbier, Celia Zubrinich.

\section{Authors' contributions}

JB proposed the concept and discussed it with JMA and WC. JPC was responsible of the Nrf2 oxidative stress section. JB and JMA wrote the paper. TZ and TH were part of the think tank group. SF and GI discussed the food data, HJC and HJK discussed the Kimchi data, AM, YH, HB, AF, GWC, JF, AV, VLM, JR, AS, $C A$ were requested to comment on the concept and to review the paper. All authors read and approved the final manuscript.

\section{Funding}

MASK-air, ARIA.

\section{Availability of data and materials \\ Not applicable.}

\section{Ethics approval and consent to participate}

Not applicable.

\section{Consent for publication}

All authors gave their informed consent.

\section{Competing interests}

None of the authors declared any competing interest.

\section{Author details}

${ }^{1}$ Department of Dermatology and Allergy, Charité, Universitätsmedizin Berlin, Humboldt-Universität Zu Berlin, Berlin Institute of Health, Comprehensive Allergy Center, Berlin, Germany. ${ }^{2}$ University Hospital Montpellier, 273 avenue d'Occitanie, 34090 Montpellier, France. ${ }^{3}$ MACVIA-France, Montpellier, France. ${ }^{4}$ Laboratoire de Biochimie et Hormonologie, PhyMedExp, Université de Montpellier, INSERM, CNRS, CHU, Montpellier, France. ${ }^{5}$ Medical Consulting Czarlewski, Levallois, France. ${ }^{6}$ MASK-Air, Montpellier, France. ${ }^{7}$ IMIM (Hospital del Mar Research Institute), Barcelona, Spain. ${ }^{8}$ Universitat Pompeu Fabra (UPF), Barcelona, Spain. ${ }^{9}$ CIBER Epidemiología y Salud Pública (CIBERESP), Barcelona, Spain. ${ }^{10}$ ISGlobAL, Barcelona, Centre for Research in Environmental Epidemiology (CREAL), Barcelona, Spain. ${ }^{11}$ Institute for Population Health Sciences, Barts and The London School of Medicine and Dentistry, Queen Mary University of London, London, UK. ${ }^{12}$ Skin and Allergy Hospital, Helsinki University Hospital, and University of Helsinki, Helsinki, Finland. ${ }^{13}$ GreenUPorto - Sustainable Agrifood Production Research Centre, DGAOT, Faculty of Sciences, University of Porto, Campus de Vairão, Vila do Conde, Portugal. ${ }^{14}$ Department of Advanced Biomedical Sciences, Federico II University, Napoli, Italy. ${ }^{15}$ Department of Geriatrics, Montpellier University Hospital, Montpellier, France. ${ }^{16}$ Division of Allergy, Department of Pediatric Medicine, The Bambino Gesu Children's Research Hospital Holy See, Rome, Italy. ${ }^{17}$ Personalized Medicine Asthma and Allergy Clinic-Humanitas University \& Research Hospital, IRCCS, Milano, Italy. ${ }^{18}$ CINTESIS, Center for Research in Health Technology and Information Systems, Faculdade de Medicina da Universidade do Porto; and Medida, Lda Porto, Porto, Portugal. ${ }^{19}$ World Business Council for Sustainable Development (WBCSD) Maison de la Paix, Geneva, Switzerland. ${ }^{20}$ AgroParisTech-Paris Institute of Technology for Life, Food and Environmental Sciences, Paris, France. ${ }^{21}$ Microbiology and Functionality Research Group, Research and Development Division, World Institute of Kimchi, Gwangju, Korea. ${ }^{22}$ SME Service Department, Strategy and Planning Division, World Institute of Kimchi, Gwangju, Korea. ${ }^{23}$ Maladies Infectieuses et Tropicales, CHU, Montpellier, France. ${ }^{24}$ The Usher Institute of Population Health Sciences and Informatics, The University of Edinburgh, Edinburgh, UK. ${ }^{25}$ Swiss Institute of Allergy and Asthma Research (SIAF), University of Zurich, Davos, Switzerland.

Received: 30 September 2020 Accepted: 12 November 2020

Published online: 03 December 2020

\section{References}

1. Kissler SM, Tedijanto C, Goldstein E, Grad YH, Lipsitch M. Projecting the transmission dynamics of SARS-CoV-2 through the postpandemic period. Science. 2020;368(6493):860-8.

2. Bousquet J, Czarlewski W, Blain H, Zuberbier T, Anto J. Rapid Response: Why Germany's case fatality rate seems so low: Is nutrition another possibility. bmj. 2020. https://www.bmj.com/content/369/bmj.m1395/ rr-12.

3. Bousquet J, Anto JM, laccarino G, Czarlewski W, Haahtela T, Anto A, et al. Is diet partly responsible for differences in COVID-19 death rates between and within countries? Clin Transl Allergy. 2020;10:16.

4. Elsayed Y, Khan NA. Immunity-boosting spices and the novel coronavirus. ACS Chem Neurosci. 2020;11(12):1696-8.

5. Bousquet J, Anto JM, Czarlewski W, Haahtela T, Fonseca SC, laccarino G, et al. Cabbage and fermented vegetables: from death rate heterogeneity in countries to candidates for mitigation strategies of severe COVID19. Allergy. 2020. https://doi.org/10.1111/all.14549.

6. Fonseca S, Rivas I, Romaguera D, Quijal M, Czarlewski W, Vidal A, et al. Association between consumption of fermented vegetables and COVID-19 mortality at a country level in Europe MEDRXIV/2020/147025 2020.

7. Fonseca S, Rivas I, Romaguera D, Quijal M, Czarlewski W, Vidal A, et al. Association between consumption of vegetables and COVID19 mortality at a country level in Europe. MedRix. 2020. https://doi. org/10.1101/2020.07.17.20155846.

8. Tonelli C, Chio IIC, Tuveson DA. Transcriptional regulation by Nrf2. Antioxid Redox Signal. 2018;29(17):1727-45.

9. Jimenez-Osorio AS, Gonzalez-Reyes S, Pedraza-Chaverri J. Natural Nrf2 activators in diabetes. Clin Chim Acta. 2015;448:182-92.

10. Pall ML, Levine S. Nrf2, a master regulator of detoxification and also antioxidant, anti-inflammatory and other cytoprotective mechanisms, is raised by health promoting factors. Sheng Li Xue Bao. 2015;67(1):1-18.

11. Iddir M, Brito A, Dingeo G, Fernandez Del Campo SS, Samouda H, La Frano MR, et al. Strengthening the immune system and reducing inflammation and oxidative stress through diet and nutrition: considerations during the COVID-19 crisis. Nutrients. 2020;12(6):1562.

12. Hassan SM, Jawad MJ, Ahjel SW, Singh RB, Singh J, Awad SM, et al. The Nrf2 activator (DMF) and covid-19: is there a possible role? Med Arch. 2020;74(2):134-8.

13. Cuadrado A, Pajares M, Benito C, Jimenez-Villegas J, Escoll M, Fernandez-Gines R, et al. Can activation of NRF2 be a strategy against COVID-19? Trends Pharmacol Sci. 2020. https://doi.org/10.1016/j. tips.2020.07.003.

14. Foldi M, Farkas N, Kiss S, Zadori N, Vancsa S, Szako L, et al. Obesity is a risk factor for developing critical condition in COVID-19 patients: a systematic review and meta-analysis. Obes Rev. 2020;21 (10):e13095.

15. Mendonca P, Soliman KFA. Flavonoids activation of the transcription factor Nrf2 as a hypothesis approach for the prevention and modulation of SARS-CoV-2 infection severity. Antioxidants (Basel). 2020;9(8):659.

16. Mocayar Maron FJ, Camargo AB, Manucha W. Allicin pharmacology: Common molecular mechanisms against neuroinflammation and cardiovascular diseases. Life Sci. 2020;249:117513.

17. Schwarz M, Lossow K, Kopp JF, Schwerdtle T, Kipp AP. Crosstalk of Nrf2 with the trace elements selenium, iron, zinc, and copper. Nutrients. 2019;11(9):2112. 
18. Berridge MJ. Vitamin D cell signalling in health and disease. Biochem Biophys Res Commun. 2015;460(1):53-71.

19. Fung TS, Liao Y, Liu DX. Regulation of stress responses and translational control by coronavirus. Viruses. 2016;8(7):184.

20. Banerjee A, Czinn SJ, Reiter RJ, Blanchard TG. Crosstalk between endoplasmic reticulum stress and anti-viral activities: a novel therapeutic target for COVID-19. Life Sci. 2020;255:117842.

21. Cui W, Li J, Ron D, Sha B. The structure of the PERK kinase domain suggests the mechanism for its activation. Acta Crystallogr D Biol Crystallogr. 2011;67(Pt 5):423-8.

22. Cnop M, Toivonen S, Igoillo-Esteve M, Salpea P. Endoplasmic reticulum stress and elF2alpha phosphorylation: the Achilles heel of pancreatic beta cells. Mol Metab. 2017:6(9):1024-39.

23. Pfefferle S, Krahling V, Ditt V, Grywna K, Muhlberger E, Drosten C. Reverse genetic characterization of the natural genomic deletion in SARS-Coronavirus strain Frankfurt-1 open reading frame $7 \mathrm{~b}$ reveals an attenuating function of the $7 \mathrm{~b}$ protein in-vitro and in-vivo. Virol $\mathrm{J}$. 2009;6:131.

24. Kindrachuk J, Ork B, Hart BJ, Mazur S, Holbrook MR, Frieman MB, et al. Antiviral potential of ERK/MAPK and PI3K/AKT/mTOR signaling modulation for Middle East respiratory syndrome coronavirus infection as identified by temporal kinome analysis. Antimicrob Agents Chemother. 2015;59(2):1088-99.

25. Rios-Fuller TJ, Mahe M, Walters B, Abbadi D, Perez-Baos S, Gadi A, et al. Translation regulation by elF2alpha phosphorylation and mTORC1 signaling pathways in Non-Communicable Diseases (NCDs). Int J Mol Sci. 2020;21(15):5301.

26. Saxton RA, Sabatini DM. mTOR Signaling in growth, metabolism, and disease. Cell. 2017;169(2):361-71.

27. Oakes SA, Papa FR. The role of endoplasmic reticulum stress in human pathology. Annu Rev Pathol. 2015:10:173-94.

28. So JS. Roles of endoplasmic reticulum stress in immune responses. Mol Cells. 2018:41(8):705-16.

29. Salvado L, Palomer X, Barroso E, Vazquez-Carrera M. Targeting endoplasmic reticulum stress in insulin resistance. Trends Endocrinol Metab. 2015;26(8):438-48.

30. Villalobos-Labra R, Subiabre M, Toledo F, Pardo F, Sobrevia L. Endoplasmic reticulum stress and development of insulin resistance in adipose skeletal, liver, and foetoplacental tissue in diabesity. Mol Aspects Med. 2019;66:49-61.

31. Li M, Wang W, Dan Y, Tong Z, Chen W, Qin L, et al. Downregulation of amplified in breast cancer 1 contributes to the anti-tumor effects of sorafenib on human hepatocellular carcinoma. Oncotarget. 2016;7(20):29605-19.

32. Cominacini L, Mozzini C, Garbin U, Pasini A, Stranieri C, Solani E, et al. Endoplasmic reticulum stress and Nrf2 signaling in cardiovascular diseases. Free Radic Biol Med. 2015;88(Pt B):233-42.

33. Yao C, Bora SA, Parimon T, Zaman T, Friedman OA, Palatinus JA, et al. Cell type-specific immune dysregulation in severely ill COVID-19 patients. medRxiv. 2020.

34. Underwood PC, Adler GK. The renin angiotensin aldosterone system and insulin resistance in humans. Curr Hypertens Rep. 2013;15(1):59-70.

35. Wen H, Gwathmey JK, Xie LH. Oxidative stress-mediated effects of angiotensin II in the cardiovascular system. World J Hypertens. 2012;2(4):34-44.

36. Bhatt SR, Lokhandwala MF, Banday AA. Vascular oxidative stress upregulates angiotensin II type I receptors via mechanisms involving nuclear factor kappa B. Clin Exp Hypertens. 2014;36(6):367-73.

37. Dalan R, Bornstein SR, El-Armouche A, Rodionov RN, Markov A, Wielockx B, et al. The ACE-2 in COVID-19: Foe or Friend? Horm Metab Res. 2020;52(5):257-63.

38. Sarzani R, Giulietti F, Di Pentima C, Giordano P, Spannella F. Disequilibrium between the classic renin-angiotensin system and its opposing arm in Sars-Cov-2 related lung injury. Am J Physiol Lung Cell Mol Physiol. 2020;319(2):L325-36.

39. Bousquet J, Anto J, Czarlewski W, Haahtela T, Fonseca S, laccarino G, et al. Sulforaphane: from death rate heterogeneity in countries to candidate for prevention of severe COVID-19 Allergy. 2020; submitted.

40. Ren $H$, Yang Y, Wang F, Yan Y, Shi X, Dong K, et al. Association of the insulin resistance marker TyG index with the severity and mortality of COVID-19. Cardiovasc Diabetol. 2020;19(1):58.
41. Villard O, Morquin D, Molinari N, Raingeard I, Nagot N, Cristol JP, et al. The plasmatic aldosterone and C-reactive protein levels, and the severity of Covid-19: the Dyhor-19 study. J Clin Med. 2020;9(7):2315.

42. Menikdiwela KR, Ramalingam L, Allen L, Scoggin S, Kalupahana NS, Moustaid-Moussa N. Angiotensin II increases endoplasmic reticulum stress in adipose tissue and adipocytes. Sci Rep. 2019;9(1):8481.

43. Cao X, Lu XM, Tuo X, Liu JY, Zhang YC, Song LN, et al. Angiotensinconverting enzyme 2 regulates endoplasmic reticulum stress and mitochondrial function to preserve skeletal muscle lipid metabolism. Lipids Health Dis. 2019;18(1):207.

44. Murugan D, Lau YS, Lau CW, Mustafa MR, Huang Y. Angiotensin 1-7 protects against angiotensin II-induced endoplasmic reticulum stress and endothelial dysfunction via mas receptor. PLOS ONE. 2015;10(12):e0145413.

45. Zhao X, Guo F, Comunale MA, Mehta A, Sehgal M, Jain P, et al. Inhibition of endoplasmic reticulum-resident glucosidases impairs severe acute respiratory syndrome coronavirus and human coronavirus NL63 spike protein-mediated entry by altering the glycan processing of angiotensin I-converting enzyme 2. Antimicrob Agents Chemother. 2015:59(1):206-16.

46. Ahmed SM, Luo L, Namani A, Wang XJ, Tang X. Nrf2 signaling pathway: Pivotal roles in inflammation. Biochim Biophys Acta Mol Basis Dis. 2017;1863(2):585-97.

47. Chen B, LuY, Chen Y, Cheng J. The role of Nrf2 in oxidative stressinduced endothelial injuries. J Endocrinol. 2015;225(3):R83-99.

48. Zhao H, Eguchi S, Alam A, Ma D. The role of nuclear factor-erythroid 2 related factor 2 (Nrf-2) in the protection against lung injury. Am J Physiol Lung Cell Mol Physiol. 2017;312(2):L155-62.

49. Jiang $T$, Harder B, de la Vega MR, Wong PK, Chapman E, Zhang DD. p62 links autophagy and Nrf2 signaling. Free Radic Biol Med. 2015;88(Pt B):199-204.

50. Abdoli A, Alirezaei M, Mehrbod P, Forouzanfar F. Autophagy: The multi-purpose bridge in viral infections and host cells. Rev Med Virol. 2018;28(4):e1973.

51. Fung TS, Liu DX. Human coronavirus: host-pathogen interaction. Annu Rev Microbiol. 2019;73:529-57.

52. Bello-Perez M, Sola I, Novoa B, Klionsky DJ, Falco A. Canonical and noncanonical autophagy as potential targets for COVID-19. Cells. 2020;9(7):1619.

53. Yang N, Shen HM. Targeting the endocytic pathway and autophagy process as a novel therapeutic strategy in COVID-19. Int J Biol Sci. 2020:16(10):1724-31.

54. Miller K, McGrath ME, Hu Z, Ariannejad S, Weston S, Frieman M, et al. Coronavirus interactions with the cellular autophagy machinery. Autophagy. 2020:1-9.

55. Calender A, Israel-Biet D, Valeyre D, Pacheco Y. Modeling potential autophagy pathways in COVID-19 and sarcoidosis. Trends Immunol. 2020;41(10):856-9.

56. Filomeni G, De Zio D, Cecconi F. Oxidative stress and autophagy: the clash between damage and metabolic needs. Cell Death Differ. 2015:22(3):377-88.

57. Ornatowski W, Lu Q, Yegambaram M, Garcia AE, Zemskov EA, Maltepe E, et al. Complex interplay between autophagy and oxidative stress in the development of pulmonary disease. Redox Biol. 2020;36:101679.

58. Dodson M, Redmann M, Rajasekaran NS, Darley-Usmar V, Zhang J. KEAP1-NRF2 signalling and autophagy in protection against oxidative and reductive proteotoxicity. Biochem J. 2015;469(3):347-55.

59. Noh JR, Kim YH, Hwang JH, Choi DH, Kim KS, Oh WK, et al. Sulforaphane protects against acetaminophen-induced hepatotoxicity. Food Chem Toxicol. 2015:80:193-200.

60. Vuong LD, Nguyen QN, Truong VL. Anti-inflammatory and anti-oxidant effects of combination between sulforaphane and acetaminophen in LPS-stimulated RAW 264.7 macrophage cells. Immunopharmacol Immunotoxicol. 2019;41(3):413-9.

61. Yaribeygi H, Farrokhi FR, Butler AE, Sahebkar A. Insulin resistance: review of the underlying molecular mechanisms. J Cell Physiol. 2019;234(6):8152-61.

62. Despres JP, Lemieux I. Abdominal obesity and metabolic syndrome. Nature. 2006;444(7121):881-7.

63. Natali A, Ferrannini E. Hypertension, insulin resistance, and the metabolic syndrome. Endocrinol Metab Clin North Am. 2004;33(2):417-29. 
64. Samson SL, Garber AJ. Metabolic syndrome. Endocrinol Metab Clin North Am. 2014;43(1):1-23.

65. Mottillo S, Filion KB, Genest J, Joseph L, Pilote L, Poirier P, et al. The metabolic syndrome and cardiovascular risk a systematic review and meta-analysis. J Am Coll Cardiol. 2010;56(14):1113-32.

66. O'Neill S, O'Driscoll L. Metabolic syndrome: a closer look at the growing epidemic and its associated pathologies. Obes Rev. 2015;16(1):1-12.

67. Muniyappa R, Sowers JR. Role of insulin resistance in endothelial dysfunction. Rev Endocr Metab Disord. 2013;14(1):5-12.

68. Artunc F, Schleicher E, Weigert C, Fritsche A, Stefan N, Haring HU. The impact of insulin resistance on the kidney and vasculature. Nat Rev Nephrol. 2016;12(12):721-37.

69. Letra L, Sena C. Cerebrovascular disease: consequences of obesityinduced endothelial dysfunction. Adv Neurobiol. 2017;19:163-89.

70. Costantino S, Paneni F, Cosentino F. Ageing, metabolism and cardiovascular disease. J Physiol. 2016;594(8):2061-73.

71. Warowicka A, Nawrot R, Gozdzicka-Jozefiak A. Antiviral activity of berberine. Arch Virol. 2020;165(9):1935-45.

72. Praditya D, Kirchhoff L, Bruning J, Rachmawati H, Steinmann J, Steinmann E. Anti-infective properties of the golden spice curcumin. Front Microbiol. 2019;10:912.

73. Divya CS, Pillai MR. Antitumor action of curcumin in human papillomavirus associated cells involves downregulation of viral oncogenes, prevention of NFKB and AP-1 translocation, and modulation of apoptosis. Mol Carcinog. 2006:45(5):320-32.

74. Hesari A, Ghasemi F, Salarinia R, Biglari H, Hassan ATM, Abdoli V, et al. Effects of curcumin on NF-kappaB, AP-1, and Wnt/beta-catenin signaling pathway in hepatitis B virus infection. J Cell Biochem. 2018;119(10):7898-904.

75. Shih LJ, Chen TF, Lin CK, Liu HS, Kao YH. Green tea (-)-epigallocatechin gallate inhibits the growth of human villous trophoblasts via the ERK, p38, AMP-activated protein kinase, and protein kinase B pathways. Am J Physiol Cell Physiol. 2016;311(2):C308-21.

76. Kesic MJ, Simmons SO, Bauer R, Jaspers I. Nrf2 expression modifies influenza A entry and replication in nasal epithelial cells. Free Radic Biol Med. 2011;51(2):444-53.

77. Furuya AK, Sharifi HJ, Jellinger RM, Cristofano P, Shi B, de Noronha CM. Sulforaphane inhibits HIV infection of macrophages through Nrf2. PLoS Pathog. 2016;12(4):e1005581.

78. Cho HY, Imani F, Miller-DeGraff L, Walters D, Melendi GA, Yamamoto M, et al. Antiviral activity of $\mathrm{Nrf} 2$ in a murine model of respiratory syncytial virus disease. Am J Respir Crit Care Med. 2009:179(2):138-50.

79. Yu JS, Chen WC, Tseng CK, Lin CK, Hsu YC, Chen YH, et al. Sulforaphane suppresses hepatitis $\mathrm{C}$ virus replication by up-regulating heme oxygenase-1 expression through PI3K/Nrf2 pathway. PLOS ONE. 2016:11(3):e0152236.

80. Shen J, Wang G, Zuo J. Caffeic acid inhibits HCV replication via induction of IFNalpha antiviral response through p62-mediated Keap1/Nrf2 signaling pathway. Antiviral Res. 2018;154:166-73.

81. Nio Y, Sasai M, Akahori Y, Okamura H, Hasegawa H, Oshima M, et al. Bardoxolone methyl as a novel potent antiviral agent against hepatitis $B$ and $C$ viruses in human hepatocyte cell culture systems. Antiviral Res. 2019:169:104537.

82. Teijaro JR. Pleiotropic roles of Type 1 interferons in antiviral immune responses. Adv Immunol. 2016;132:135-58.

83. Motwani M, Pesiridis S, Fitzgerald KA. DNA sensing by the cGAS-STING pathway in health and disease. Nat Rev Genet. 2019;20(11):657-74.

84. Olagnier D, Brandtoft AM, Gunderstofte C, Villadsen NL, Krapp C, Thielke $\mathrm{AL}$, et al. Nrf2 negatively regulates STING indicating a link between antiviral sensing and metabolic reprogramming. Nat Commun. 2018;9(1):3506.

85. Gunderstofte C, Iversen MB, Peri S, Thielke A, Balachandran S, Holm CK, et al. Nrf2 Negatively regulates Type I interferon responses and increases susceptibility to herpes genital infection in mice. Front Immunol. 2019;10:2101.

86. Mills EL, Ryan DG, Prag HA, Dikovskaya D, Menon D, Zaslona Z, et al. Itaconate is an anti-inflammatory metabolite that activates Nrf2 via alkylation of KEAP1. Nature. 2018;556(7699):113-7.

87. Wang ZS, Lu FE, Xu LJ, Dong H. Berberine reduces endoplasmic reticulum stress and improves insulin signal transduction in Hep G2 cells. Acta Pharmacol Sin. 2010:31(5):578-84
88. Kobori M, Takahashi Y, Takeda H, Takahashi M, Izumi Y, Akimoto Y, et al. Dietary intake of curcumin improves elF2 signaling and reduces lipid levels in the white adipose tissue of obese mice. Sci Rep. 2018:8(1):9081.

89. Md Nesran ZN, Shafie NH, Ishak AH, Mohd Esa N, Ismail A, Md Tohid SF. Induction of endoplasmic reticulum stress pathway by green tea epigallocatechin-3-gallate (EGCG) in colorectal cancer cells: activation of PERK/p-elF2alpha/ATF4 and IRE1alpha. Biomed Res Int. 2019;2019:3480569.

90. Modernelli A, Naponelli V, Giovanna Troglio M, Bonacini M, Ramazzina I, Bettuzzi S, et al. EGCG antagonizes Bortezomib cytotoxicity in prostate cancer cells by an autophagic mechanism. Sci Rep. 2015;5:15270.

91. Xia S, Wang J, Kalionis B, Zhang W, Zhao Y. Genistein protects against acute pancreatitis via activation of an apoptotic pathway mediated through endoplasmic reticulum stress in rats. Biochem Biophys Res Commun. 2019;509(2):421-8.

92. Nanua S, Zick SM, Andrade JE, Sajjan US, Burgess JR, Lukacs NW, et al. Quercetin blocks airway epithelial cell chemokine expression. Am J Respir Cell Mol Biol. 2006;35(5):602-10.

93. Yu CL, Yang SF, Hung TW, Lin CL, Hsieh YH, Chiou HL. Inhibition of elF2alpha dephosphorylation accelerates pterostilbene-induced cell death in human hepatocellular carcinoma cells in an ER stress and autophagy-dependent manner. Cell Death Dis. 2019;10(6):418.

94. Palomera-Avalos V, Grinan-Ferre C, Izquierdo V, Camins A, Sanfeliu C, Canudas AM, et al. Resveratrol modulates response against acute inflammatory stimuli in aged mouse brain. Exp Gerontol. 2018;102:3-11.

95. Zhang C, Zhou Y, Zhou Y, Lu Y, Wang D. Regulation of elF2alpha expression and renal interstitial fibrosis by resveratrol in rat renal tissue after unilateral ureteral obstruction. Ren Fail. 2016;38(4):622-8.

96. Liu J, Fan C, Yu L, Yang Y, Jiang S, Ma Z, et al. Pterostilbene exerts an anti-inflammatory effect via regulating endoplasmic reticulum stress in endothelial cells. Cytokine. 2016;77:88-97.

97. Zhou Q, Chen B, Wang X, Wu L, Yang Y, Cheng X, et al. Sulforaphane protects against rotenone-induced neurotoxicity in vivo: Involvement of the mTOR, Nrf2, and autophagy pathways. Sci Rep. 2016;6:32206.

98. Zhang Y, Gilmour A, Ahn YH, de la Vega L, Dinkova-Kostova AT. The isothiocyanate sulforaphane inhibits mTOR in an NRF2-independent manner. Phytomedicine. 2019. https://doi.org/10.1016/j.phyme d.2019.153062.

99. Woo M, Kim M, Noh JS, Park CH, Song YO. Kimchi attenuates fatty streak formation in the aorta of low-density lipoprotein receptor knockout mice via inhibition of endoplasmic reticulum stress and apoptosis. Nutr Res Pract. 2017;11 (6):445-51.

100. Woo M, Kim MJ, Song YO. Bioactive compounds in kimchi improve the cognitive and memory functions impaired by amyloid beta. Nutrients. 2018:10(10):1554.

101. Woo M, Noh JS, Cho EJ, Song YO. Bioactive compounds of kimchi inhibit apoptosis by attenuating endoplasmic reticulum stress in the brain of amyloid beta-injected mice. J Agric Food Chem. 2018;66(19):4883-90.

102. Kim HJ, Noh JS, Song YO. Beneficial effects of kimchi, a korean fermented vegetable food, on pathophysiological factors related to atherosclerosis. J Med Food. 2018;21 (2):127-35.

103. Joo HK, Choi S, Lee YR, Lee EO, Park MS, Park KB, et al. Anthocyanin-rich extract from red chinese cabbage alleviates vascular inflammation in endothelial cells and apo E(-/-) mice. Int J Mol Sci. 2018;19(3):816.

104. Shin JS, Noh YS, Lee YS, Cho YW, Baek NI, Choi MS, et al. Arvelexin from brassica rapa suppresses NF-kappaB-regulated pro-inflammatory gene expression by inhibiting activation of IkappaB kinase. Br J Pharmacol. 2011:164(1):145-58.

105. Yao Y, Wang W, Li M, Ren H, Chen C, Wang J, et al. Curcumin Exerts its anti-hypertensive effect by down-regulating the AT1 receptor in vascular smooth muscle cells. Sci Rep. 2016;6:25579.

106. Zhan XL, Yang XH, Gu YH, Guo LL, Jin HM. Epigallocatechin gallate protects against homocysteine-induced vascular smooth muscle cell proliferation. Mol Cell Biochem. 2018:439(1-2):131-40.

107. Malhotra A, Kang BP, Cheung S, Opawumi D, Meggs LG. Angiotensin II promotes glucose-induced activation of cardiac protein kinase $\mathrm{C}$ isozymes and phosphorylation of troponin I. Diabetes. 2001;50(8):1918-26. 
108. Anandanadesan R, Gong Q, Chipitsyna G, Witkiewicz A, Yeo CJ, Arafat HA. Angiotensin II induces vascular endothelial growth factor in pancreatic cancer cells through an angiotensin II type 1 receptor and ERK1/2 signaling. J Gastrointest Surg. 2008;12(1):57-66.

109. Gao Y, Kang L, Li C, Wang X, Sun C, Li Q, et al. Resveratrol ameliorates diabetes-induced cardiac dysfunction through AT1R-ERK/p38 MAPK signaling pathway. Cardiovasc Toxicol. 2016;16(2):130-7.

110. Yousefian M, Shakour N, Hosseinzadeh H, Hayes AW, Hadizadeh F, Karimi G. The natural phenolic compounds as modulators of $\mathrm{NADPH}$ oxidases in hypertension. Phytomedicine. 2019;55:200-13.

111. Karimian MS, Pirro M, Johnston TP, Majeed M, Sahebkar A. Curcumin and endothelial function: evidence and mechanisms of protective effects. Curr Pharm Des. 2017;23(17):2462-73.

112. Zhang $M, X u Y$, Qiu Z, Jiang L. Sulforaphane attenuates angiotensin Il-induced vascular smooth muscle cell migration via suppression of NOX4/ROS/Nrf2 Signaling. Int J Biol Sci. 2019;15(1):148-57.

113. Bendavit G, Aboulkassim T, Hilmi K, Shah S, Batist G. Nrf2 Transcription factor can directly regulate mTOR: Linking cytoprotective gene expression to a major metabolic regulator that generates redox activity. J Biol Chem. 2016;291(49):25476-88.

114. Maiese K. The mechanistic target of rapamycin (mTOR): novel considerations as an antiviral treatment. Curr Neurovasc Res. 2020;17(3):332-7.

115. Nilius B, Appendino G. Spices: the savory and beneficial science of pungency. Rev Physiol Biochem Pharmacol. 2013;164:1-76.

116. Jordt SE, Bautista DM, Chuang HH, McKemy DD, Zygmunt PM, Hogestatt ED, et al. Mustard oils and cannabinoids excite sensory nerve fibres through the TRP channel ANKTM1. Nature. 2004;427(6971):260-5.

117. Tan SM, de Haan JB. Combating oxidative stress in diabetic complications with Nrf2 activators: how much is too much? Redox Rep. 2014;19(3):107-17.

118. Silva-Islas CA, Maldonado PD. Canonical and non-canonical mechanisms of Nrf2 activation. Pharmacol Res. 2018;134:92-9.

119. Nair S, Doh ST, Chan JY, Kong AN, Cai L. Regulatory potential for concerted modulation of Nrf2- and Nfkb1-mediated gene expression in inflammation and carcinogenesis. Br J Cancer. 2008;99(12):2070-82.

120. Chen KK, Minakuchi M, Wuputra K, Ku CC, Pan JB, Kuo KK, et al. Redox control in the pathophysiology of influenza virus infection. BMC Microbiol. 2020;20(1):214.

121. Pedruzzi LM, Stockler-Pinto MB, Leite M Jr, Mafra D. Nrf2-keap1 system versus NF-kappaB: the good and the evil in chronic kidney disease? Biochimie. 2012;94(12):2461-6.

122. Cecchini R, Cecchini AL. SARS-CoV-2 infection pathogenesis is related to oxidative stress as a response to aggression. Med Hypotheses. 2020;143:110102.

123. Hawiger J, Zienkiewicz J. Decoding inflammation, its causes, genomic responses, and emerging countermeasures. Scand J Immunol. 2019;90(6):e12812.

124. Morena M, Cristol JP, Senecal L, Leray-Moragues H, Krieter D, Canaud B. Oxidative stress in hemodialysis patients: is NADPH oxidase complex the culprit? Kidney Int Suppl. 2002;80:109-14.

125. Kurutas EB. The importance of antioxidants which play the role in cellular response against oxidative/nitrosative stress: current state. Nutr J. 2016;15(1):71

126. Delgado-Roche L, Riera-Romo M, Mesta F, Hernandez-Matos Y, Barrios JM, Martinez-Sanchez G, et al. Medical ozone promotes Nrf2 phosphorylation reducing oxidative stress and pro-inflammatory cytokines in multiple sclerosis patients. Eur J Pharmacol. 2017;811:148-54.

127. Song MG, Ryoo IG, Choi HY, Choi BH, Kim ST, Heo TH, et al. NRF2 signaling negatively regulates Phorbol-12-Myristate-13-Acetate (PMA)-induced differentiation of human monocytic U937 cells into proinflammatory macrophages. PLoS ONE. 2015;10(7):e0134235.

128. Herpers B, Wink S, Fredriksson L, Di Z, Hendriks G, Vrieling H, et al. Activation of the Nrf2 response by intrinsic hepatotoxic drugs correlates with suppression of NF-kappaB activation and sensitizes toward TNFalpha-induced cytotoxicity. Arch Toxicol. 2016;90(5):1163-79.

129. Li W, Khor TO, Xu C, Shen G, Jeong WS, Yu S, et al. Activation of Nrf2antioxidant signaling attenuates NFkappaB-inflammatory response and elicits apoptosis. Biochem Pharmacol. 2008;76(11):1485-9.

130. Mohan S, Gupta D. Crosstalk of toll-like receptors signaling and Nrf2 pathway for regulation of inflammation. Biomed Pharmacother. 2018:108:1866-78.
131. Wardyn JD, Ponsford AH, Sanderson CM. Dissecting molecular cross-talk between Nrf2 and NF-kappaB response pathways. Biochem Soc Trans. 2015;43(4):621-6.

132. Clavo B, Rodriguez-Esparragon F, Rodriguez-Abreu D, Martinez-Sanchez G, Llontop P, Aguiar-Bujanda D, et al. Modulation of oxidative stress by ozone therapy in the prevention and treatment of chemotherapy-induced toxicity: review and prospects. Antioxidants (Basel). 2019;8(12):588.

133. Leon OS, Menendez S, Merino N, Castillo R, Sam S, Perez L, et al. Ozone oxidative preconditioning: a protection against cellular damage by free radicals. Mediators Inflamm. 1998;7(4):289-94.

134. Khatlani T, Algudiri D, Alenzi R, Al Subayyil AM, Abomaray FM, Bahattab

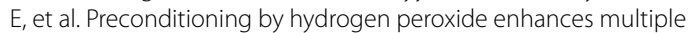
properties of human decidua basalis mesenchymal stem/multipotent stromal cells. Stem Cells Int. 2018;2018:6480793.

135. Vide J, Virsolvy A, Romain C, Ramos J, Jouy N, Richard S, et al. Dietary silicon-enriched spirulina improves early atherosclerosis markers in hamsters on a high-fat diet. Nutrition. 2015;31(9):1148-54.

136. Al-Awwadi NA, Araiz C, Bornet A, Delbosc S, Cristol JP, Linck N, et al. Extracts enriched in different polyphenolic families normalize increased cardiac NADPH oxidase expression while having differential effects on insulin resistance, hypertension, and cardiac hypertrophy in highfructose-fed rats. J Agric Food Chem. 2005;53(1):151-7.

137. Sinha N, Dabla PK. Oxidative stress and antioxidants in hypertension-a current review. Curr Hypertens Rev. 2015;11(2):132-42.

138. Martinez-Sanchez G, Schwartz A, Donna VD. Potential cytoprotective activity of ozone therapy in SARS-CoV-2/COVID-19. Antioxidants (Basel). 2020;9(5):389

139. Hybertson BM, Gao B, Bose SK, McCord JM. Oxidative stress in health and disease: the therapeutic potential of Nrf2 activation. Mol Aspects Med. 2011:32(4-6):234-46.

140. Dodson M, de la Vega MR, Cholanians AB, Schmidlin CJ, Chapman E, Zhang DD. Modulating NRF2 in Disease: timing Is everything. Annu Rev Pharmacol Toxicol. 2019;59:555-75.

141. Hayashi G, Jasoliya M, Sahdeo S, Sacca F, Pane C, Filla A, et al. Dimethyl fumarate mediates Nrf2-dependent mitochondrial biogenesis in mice and humans. Hum Mol Genet. 2017;26(15):2864-73.

142. Satoh T, Lipton S. Recent advances in understanding NRF2 as a druggable target: development of pro-electrophilic and non-covalent NRF2 activators to overcome systemic side effects of electrophilic drugs like dimethyl fumarate. F1000Res. 2017;6:2138.

143. Saidu NEB, Kavian N, Leroy K, Jacob C, Nicco C, Batteux F, et al. Dimethy fumarate, a two-edged drug: current status and future directions. Med Res Rev. 2019;39(5):1923-52.

144. Moreno JA, Gomez-Guerrero C, Mas S, Sanz AB, Lorenzo O, Ruiz-Ortega $M$, et al. Targeting inflammation in diabetic nephropathy: a tale of hope. Expert Opin Investig Drugs. 2018;27(11):917-30.

145. Collaboration NCDRF. Trends in adult body-mass index in 200 countries from 1975 to 2014: a pooled analysis of 1698 populationbased measurement studies with 19.2 million participants. Lancet. 2016:387(10026):1377-96.

146. Addo J, Agyemang C, de Aikins GA, Beune E, Schulze MB, Danquah I, et al. Association between socioeconomic position and the prevalence of type 2 diabetes in Ghanaians in different geographic locations: the RODAM study. J Epidemiol Community Health. 2017;71(7):633-9.

147. Agyemang C, Beune E, Meeks K, Addo J, Aikins AD, Bahendeka S, et al. Innovative ways of studying the effect of migration on obesity and diabetes beyond the common designs: lessons from the RODAM study. Ann N Y Acad Sci. 2017;1391(1):54-70.

148. Agyemang C, Meeks K, Beune E, Owusu-Dabo E, Mockenhaupt FP, Addo J, et al. Obesity and type 2 diabetes in sub-Saharan Africans-is the burden in today's Africa similar to African migrants in Europe? The RODAM study. BMC Med. 2016;14(1):166.

149. Boateng D, Agyemang C, Beune E, Meeks K, Smeeth L, Schulze M, et al. Migration and cardiovascular disease risk among ghanaian populations in Europe: the RODAM Study (Research on Obesity and Diabetes Among African Migrants). Circ Cardiovasc Qual Outcomes. 2017;10(11):e004013.

150. Chilunga FP, Henneman P, Meeks KA, Beune E, Requena-Mendez A, Smeeth $\mathrm{L}$, et al. Prevalence and determinants of type 2 diabetes among 
lean African migrants and non-migrants: the RODAM study. J Glob Health. 2019;9(2):020426.

151. Galbete C, Nicolaou M, Meeks K, Klipstein-Grobusch K, de Aikins GA Addo J, et al. Dietary patterns and type 2 diabetes among Ghanaian migrants in Europe and their compatriots in Ghana: the RODAM study. Nutr Diabetes. 2018;8(1):25.

152. Boateng D, Galbete C, Nicolaou M, Meeks K, Beune E, Smeeth L, et al. Dietary patterns are associated with predicted 10 -year risk of cardiovascular disease among ghanaian populations: the research on obesity and diabetes in african migrants (RODAM) study. J Nutr. 2019;149(5):755-69.

153. Danquah I, Galbete C, Meeks K, Nicolaou M, Klipstein-Grobusch K, Addo J, et al. Food variety, dietary diversity, and type 2 diabetes in a multi-center cross-sectional study among Ghanaian migrants in Europe and their compatriots in Ghana: the RODAM study. Eur J Nutr. 2018;57(8):2723-33.

154. Nam GE, Kim YH, Han K, Jung JH, Park YG, Lee KW, et al. Obesity fact sheet in Korea, 2018: data focusing on waist circumference and obesityrelated comorbidities. J Obes Metab Syndr. 2019;28(4):236-45.

155. Finer N, Garnett SP, Bruun JM. COVID-19 and obesity. Clin Obes. 2020;10(3):e12365.

156. Tartof SY, Qian L, Hong V, Wei R, Nadjafi RF, Fischer H, et al. Obesity and mortality among patients diagnosed With COVID-19: results from an integrated health care organization. Ann Intern Med. 2020. https://doi. org/10.7326/M20-3742.

157. Kass DA. COVID-19 and severe obesity: a big problem? Ann Intern Med. 2020. https://doi.org/10.7326/M20-5677.

158. Klang E, Kassim G, Soffer S, Freeman R, Levin MA, Reich DL. Severe Obesity as an Independent Risk Factor for COVID-19 Mortality in Hospitalized Patients Younger than 50. Obesity (Silver Spring). 2020.

159. Holman N, Knighton P, Kar P, O'Keefe J, Curley M, Weaver A, et al. Risk factors for COVID-19-related mortality in people with type 1 and type 2 diabetes in England: a population-based cohort study. Lancet Diabetes Endocrinol. 2020;8(10):823-33.

160. Negi CK, Jena G. Nrf2, a novel molecular target to reduce type 1 diabetes associated secondary complications: the basic considerations. Eur J Pharmacol. 2019;843:12-26.

161. Asbaghi O, Ghanbari N, Shekari M, Reiner Z, Amirani E, Hallajzadeh $J$, et al. The effect of berberine supplementation on obesity parameters, inflammation and liver function enzymes: a systematic review and meta-analysis of randomized controlled trials. Clin Nutr ESPEN. 2020:38:43-9.

162. Li T, Yang GM, Zhu Y, Wu Y, Chen XY, Lan D, et al. Diabetes and hyperlipidemia induce dysfunction of VSMCs: contribution of the metabolic inflammation/miRNA pathway. Am J Physiol Endocrinol Metab. 2015;308(4):E257-69.

163. Zhao Y, Chen B, Shen J, Wan L, Zhu Y, Yi T, et al. The beneficial effects of quercetin, curcumin, and resveratrol in obesity. Oxid Med Cell Longev. 2017:2017:1459497.

164. Goktas Z, Zu Y, Abbasi M, Galyean S, Wu D, Fan Z, et al. Recent advances in nano-encapsulation of phytochemicals to combat obesity and its comorbidities. J Agric Food Chem. 2020;68(31):8119-31.

165. Mukund V, Mukund D, Sharma V, Mannarapu M, Alam A. Genistein: Its role in metabolic diseases and cancer. Crit Rev Oncol Hematol. 2017:119:13-22.

166. Xu L, Nagata N, Ota T. Glucoraphanin: a broccoli sprout extract that ameliorates obesity-induced inflammation and insulin resistance. Adipocyte. 2018;7(3):218-25.

167. Kunnumakkara AB, Bordoloi D, Padmavathi G, Monisha J, Roy NK, Prasad $\mathrm{S}$, et al. Curcumin, the golden nutraceutical: multitargeting for multiple chronic diseases. Br J Pharmacol. 2017;174(11):1325-48.

168. Crovesy L, Ostrowski M, Ferreira D, Rosado EL, Soares-Mota M. Effect of lactobacillus on body weight and body fat in overweight subjects: a systematic review of randomized controlled clinical trials. Int J Obes (Lond). 2017;41(11):1607-14.

169. Lim S, Moon JH, Shin CM, Jeong D, Kim B. Effect of lactobacillus sakei, a probiotic derived from kimchi, on body fat in koreans with obesity: a randomized controlled study. Endocrinol Metab (Seoul). 2020;35(2):425-34.
170. Martins T, Colaco B, Venancio C, Pires MJ, Oliveira PA, Rosa E, et al. Potential effects of sulforaphane to fight obesity. J Sci Food Agric. 2018;98(8):2837-44

171. Zhang Z, Zhou S, Jiang X, Wang YH, Li F, Wang YG, et al. The role of the $\mathrm{Nrf} /$ Keap1 pathway in obesity and metabolic syndrome. Rev Endocr Metab Disord. 2015;16(1):35-45.

172. Bayliak MM, Abrat OB, Storey JM, Storey KB, Lushchak VI. Interplay between diet-induced obesity and oxidative stress: comparison between drosophila and mammals. Comp Biochem Physiol A Mol Integr Physiol. 2019;228:18-28.

173. Ashrafizadeh M, Fekri HS, Ahmadi Z, Farkhondeh T, Samarghandian S. Therapeutic and biological activities of berberine: the involvement of Nrf2 signaling pathway. J Cell Biochem. 2020;121(2):1575-85.

174. Tabeshpour J, Imenshahidi M, Hosseinzadeh $\mathrm{H}$. A review of the effects of Berberis vulgaris and its major component, berberine, in metabolic syndrome. Iran J Basic Med Sci. 2017;20(5):557-68.

175. Qiu H, Wu Y, Wang Q, Liu C, Xue L, Wang H, et al. Effect of berberine on PPARalpha-NO signalling pathway in vascular smooth muscle cell proliferation induced by angiotensin IV. Pharm Biol. 2017;55(1):227-32.

176. Xu Z, Feng W, Shen Q, Yu N, Yu K, Wang S, et al. Rhizoma Coptidis and Berberine as a natural drug to combat aging and aging-related diseases via anti-oxidation and AMPK activation. Aging Dis. 2017;8(6):760-77.

177. Hadi A, Pourmasoumi M, Ghaedi E, Sahebkar A. The effect of Curcumin/ Turmeric on blood pressure modulation: a systematic review and metaanalysis. Pharmacol Res. 2019;150:104505.

178. Pivari F, Mingione A, Brasacchio C, Soldati L. Curcumin and type 2 diabetes mellitus: prevention and treatment. Nutrients. 2019;11(8):1837.

179. Hallajzadeh J, Milajerdi A, Kolahdooz F, Amirani E, Mirzaei H, Asemi Z. The effects of curcumin supplementation on endothelial function: a systematic review and meta-analysis of randomized controlled trials. Phytother Res. 2019:33(11):2989-95.

180. Malavolta M, Bracci M, Santarelli L, Sayeed MA, Pierpaoli E, Giacconi R, et al. Inducers of senescence, toxic compounds, and senolytics: the multiple faces of Nrf2-activating phytochemicals in cancer adjuvant therapy. Mediators Inflamm. 2018;2018:4159013.

181. Gouda MM, Bhandary YP. Acute lung injury: IL-17A-mediated inflammatory pathway and its regulation by curcumin. Inflammation. 2019:42(4):1160-9.

182. Lelli D, Sahebkar A, Johnston TP, Pedone C. Curcumin use in pulmonary diseases: state of the art and future perspectives. Pharmacol Res. 2017;115:133-48.

183. Mohammadi A, Blesso CN, Barreto GE, Banach M, Majeed M, Sahebkar A. Macrophage plasticity, polarization and function in response to curcumin, a diet-derived polyphenol, as an immunomodulatory agent. J Nutr Biochem. 2019;66:1-16.

184. Yamagata K. Polyphenols regulate endothelial functions and reduce the risk of cardiovascular disease. Curr Pharm Des. 2019a;25(22):2443-58.

185. Khan N, Mukhtar H. Tea polyphenols in promotion of human health. Nutrients. 2018;11(1):39.

186. Favarin DC, de Oliveira JR, de Oliveira CJ, Rogerio AP. Potential effects of medicinal plants and secondary metabolites on acute lung injury. Biomed Res Int. 2013;2013:576479.

187. Wang J, Fan SM, Zhang J. Epigallocatechin-3-gallate ameliorates lipopolysaccharide-induced acute lung injury by suppression of TLR4/ NF-kappaB signaling activation. Braz J Med Biol Res. 2019;52(7):e8092.

188. Martinez G, Mijares MR, De Sanctis JB. Effects of Flavonoids and Its derivatives on immune cell responses. Recent Pat Inflamm Allergy Drug Discov. 2019;13(2):84-104

189. Yamagata K. Soy isoflavones inhibit endothelial cell dysfunction and prevent cardiovascular disease. J Cardiovasc Pharmacol. 2019b;74(3):201-9.

190. Weng L, Zhang F, Wang R, Ma W, Song Y. A review on protective role of genistein against oxidative stress in diabetes and related complications. Chem Biol Interact. 2019:310:108665.

191. Yi L, Chang M, Zhao Q, Zhou Z, Huang X, Guo F, et al. Genistein3'-sodium sulphonate protects against lipopolysaccharide-induced lung vascular endothelial cell apoptosis and acute lung injury via BCL-2 signalling. J Cell Mol Med. 2020;24(1):1022-35.

192. Spagnuolo C, Moccia S, Russo GL. Anti-inflammatory effects of flavonoids in neurodegenerative disorders. Eur J Med Chem. 2018:153:105-15. 
193. Lewis-Mikhael AM, Davoodvandi A, Jafarnejad S. Effect of Lactobacillusplantarum containing probiotics on blood pressure: a systematic review and meta-analysis. Pharmacol Res. 2020;153:104663.

194. Azad MAK, Sarker M, Li T, Yin J. Probiotic species in the modulation of gut microbiota: an overview. Biomed Res Int. 2018;2018:9478630.

195. Skonieczna-Zydecka K, Kazmierczak-Siedlecka K, Kaczmarczyk M, SliwaDominiak J, Maciejewska D, Janda K, et al. The Effect of probiotics and synbiotics on risk factors associated with cardiometabolic diseases in healthy people-a systematic review and meta-analysis with metaregression of randomized controlled trials. J Clin Med. 2020;9(6):1788.

196. Malaguarnera G, Leggio F, Vacante M, Motta M, Giordano M, Bondi A, et al. Probiotics in the gastrointestinal diseases of the elderly. J Nutr Health Aging. 2012;16(4):402-10.

197. Khailova L, Petrie B, Baird CH, Dominguez Rieg JA, Wischmeyer PE. Lactobacillus rhamnosus $\mathrm{GG}$ and Bifidobacterium longum attenuate lung injury and inflammatory response in experimental sepsis. PLoS ONE. 2014;9(5):e97861.

198. Percopo CM, Ma M, Brenner TA, Krumholz JO, Break TJ, Laky K, et al. Critical adverse impact of IL-6 in acute pneumovirus infection. J Immunol. 2019:202(3):871-82

199. Marunaka Y, Marunaka R, Sun H, Yamamoto T, Kanamura N, Inui T, et al. Actions of quercetin, a polyphenol, on blood pressure. Molecules. 2017;22(2):209.

200. Eid HM, Haddad PS. The antidiabetic potential of quercetin: underlying mechanisms. Curr Med Chem. 2017;24(4):355-64.

201. Gerin F, Sener U, Erman H, Yilmaz A, Aydin B, Armutcu F, et al. The effects of quercetin on acute lung injury and biomarkers of inflammation and oxidative stress in the rat model of sepsis. Inflammation. 2016;39(2):700-5.

202. Peluso I, Raguzzini A, Serafini M. Effect of flavonoids on circulating levels of TNF-alpha and IL-6 in humans: a systematic review and metaanalysis. Mol Nutr Food Res. 2013;57(5):784-801.

203. Bonnefont-Rousselot D. Resveratrol and cardiovascular diseases. Nutrients. 2016;8(5):250.

204. Ozturk E, Arslan AKK, Yerer MB, Bishayee A. Resveratrol and diabetes: a critical review of clinical studies. Biomed Pharmacother. 2017:95:230-4.

205. Li H, Xia N, Hasselwander S, Daiber A. Resveratrol and vascular function. Int J Mol Sci. 2019;20(9):2155.

206. Conte E, Fagone E, Fruciano M, Gili E, lemmolo M, Vancheri C. Antiinflammatory and antifibrotic effects of resveratrol in the lung. Histol Histopathol. 2015;30(5):523-9.

207. Koushki M, Dashatan NA, Meshkani R. Effect of resveratrol supplementation on inflammatory markers: a systematic review and meta-analysis of randomized controlled trials. Clin Ther. 2018;40(7):1180-92 e5.

208. Patel B, Mann GE, Chapple SJ. Concerted redox modulation by sulforaphane alleviates diabetes and cardiometabolic syndrome. Free Radic Biol Med. 2018;122:150-60.

209. Cox AG, Gurusinghe S, Abd Rahman R, Leaw B, Chan ST, Mockler JC, et al. Sulforaphane improves endothelial function and reduces placental oxidative stress in vitro. Pregnancy Hypertens. 2019;16:1-10.

210. Zhao B, Gao W, Gao X, Leng Y, Liu M, Hou J, et al. Sulforaphane attenuates acute lung injury by inhibiting oxidative stress via $\mathrm{Nrf2/HO}-1$ pathway in a rat sepsis model. Int J Clin Exp Pathol. 2017:10(8):9021-8.

211. Xie C, Zhu J, Jiang Y, Chen J, Wang X, Geng S, et al. Sulforaphane inhibits the acquisition of tobacco smoke-induced lung cancer stem cell-like properties via the IL-6/DeltaNp63alpha/Notch axis. Theranostics. 2019;9(16):4827-40.

212. Huang C, Zhang Y, Gong Z, Sheng X, Li Z, Zhang W, et al. Berberine inhibits 3T3-L1 adipocyte differentiation through the PPARgamma pathway. Biochem Biophys Res Commun. 2006;348(2):571-8.

213. Patel SS, Acharya A, Ray RS, Agrawal R, Raghuwanshi R, Jain P. Cellular and molecular mechanisms of curcumin in prevention and treatment of disease. Crit Rev Food Sci Nutr. 2020;60(6):887-939.

214. Zhou H, Luo Y, Huang S. Updates of mTOR inhibitors. Anticancer Agents Med Chem. 2010;10(7):571-81.

215. Babu PV, Liu D, Gilbert ER. Recent advances in understanding the anti-diabetic actions of dietary flavonoids. J Nutr Biochem. 2013;24(11):1777-89.

216. Negri A, Naponelli V, Rizzi F, Bettuzzi S. Molecular targets of epigallocatechin-gallate (EGCG): a special focus on signal transduction and cancer. Nutrients. 2018:10(12):1936.
217. Dhatwalia SK, Kumar M, Dhawan DK. Role of EGCG in containing the progression of lung tumorigenesis - a multistage targeting approach. Nutr Cancer. 2018:70(3):334-49.

218. Tan HK, Moad Al, Tan ML. The mTOR signalling pathway in cancer and the potential mTOR inhibitory activities of natural phytochemicals. Asian Pac J Cancer Prev. 2014;15(16):6463-75.

219. Wang L, Waltenberger B, Pferschy-Wenzig EM, Blunder M, Liu X, Malainer $C$, et al. Natural product agonists of peroxisome proliferatoractivated receptor gamma (PPARgamma): a review. Biochem Pharmacol. 2014;92(1):73-89.

220. Gupta SC, Kunnumakkara AB, Aggarwal S, Aggarwal BB. Inflammation, a double-edge sword for cancer and other age-related diseases. Front Immunol. 2018:9:2160.

221. Pordanjani SM, Hosseinimehr SJ. The role of NF-kB inhibitors in cell response to radiation. Curr Med Chem. 2016;23(34):3951-63.

222. Dkhar B, Khongsti K, Thabah D, Syiem D, Satyamoorthy K, Das B. Genistein represses PEPCK-C expression in an insulin-independent manner in HepG2 cells and in alloxan-induced diabetic mice. J Cell Biochem. 2018;119(2):1953-70.

223. Kong Y, Olejar KJ, On SLW, Chelikani V. The potential of Lactobacillus spp. for modulating oxidative stress in the gastrointestinal tract. Antioxidants (Basel). 2020;9(7):610.

224. Wang H, Cheng X, Zhang L, Xu S, Zhang Q, Lu R. A surface-layer protein from Lactobacillus acidophilus NCFM induces autophagic death in HCT116 cells requiring ROS-mediated modulation of MTOR and JNK signaling pathways. Food Funct. 2019;10(7):4102-12.

225. Kim DH, Jeong D, Kang IB, Kim H, Song KY, Seo KH. Dual function of Lactobacillus kefiri DH5 in preventing high-fat-diet-induced obesity: direct reduction of cholesterol and upregulation of PPAR-alpha in adipose tissue. Mol Nutr Food Res. 2017;61(11):1700252.

226. Jeong M, Kim JH, Yang H, Kang SD, Song S, Lee D, et al. Heat-Killed Lactobacillus plantarum KCTC 13314BP enhances phagocytic activity and immunomodulatory effects via activation of MAPK and STAT3 pathways. J Microbiol Biotechnol. 2019;29(8):1248-54.

227. Sanches-Silva A, Testai L, Nabavi SF, Battino M, Pandima Devi K, Tejada S, et al. Therapeutic potential of polyphenols in cardiovascular diseases: regulation of mTOR signaling pathway. Pharmacol Res. 2020;152:104626.

228. Chekalina N, Burmak Y, Petrov Y, Borisova Z, Manusha Y, Kazakov Y, et al. Quercetin reduces the transcriptional activity of NF-kB in stable coronary artery disease. Indian Heart J. 2018;70(5):593-7.

229. Shaik Y, Caraffa A, Ronconi G, Lessiani G, Conti P. Impact of polyphenols on mast cells with special emphasis on the effect of quercetin and luteolin. Cent Eur J Immunol. 2018;43(4):476-81.

230. Widlund AL, Baur JA, Vang O. mTOR: more targets of resveratrol? Expert Rev Mol Med. 2013:15:e10.

231. Shawky NM, Segar L. Sulforaphane inhibits platelet-derived growth factor-induced vascular smooth muscle cell proliferation by targeting mTOR/p70S6kinase signaling independent of Nrf2 activation. Pharmacol Res. 2017;119:251-64.

232. Jo C, Kim S, Cho SJ, Choi KJ, Yun SM, Koh YH, et al. Sulforaphane induces autophagy through ERK activation in neuronal cells. FEBS Lett. 2014;588(17):3081-8.

233. Doudican NA, Wen SY, Mazumder A, Orlow SJ. Sulforaphane synergistically enhances the cytotoxicity of arsenic trioxide in multiple myeloma cells via stress-mediated pathways. Oncol Rep. 2012;28(5):1851-8.

234. Rocha FAC, de Assis MR. Curcumin as a potential treatment for COVID19. Phytother Res. 2020. https://doi.org/10.1002/ptr.6745.

235. Roy A, Sarkar B, Celik C, Ghosh A, Basu U, Jana M, et al. Can concomitant use of zinc and curcumin with other immunity-boosting nutraceuticals be the arsenal against COVID-19? Phytother Res. 2020. https://doi. org/10.1002/ptr.6766.

236. Zahedipour F, Hosseini SA, Sathyapalan T, Majeed M, Jamialahmadi T, AlRasadi K, et al. Potential effects of curcumin in the treatment of COVID19 infection. Phytother Res. 2020. https://doi.org/10.1002/ptr.6738.

237. Gupta H, Gupta M, Bhargava S. Potential use of turmeric in COVID-19. Clin Exp Dermatol. 2020;45(7):902-3.

238. Xu J, Xu Z, Zheng W. A review of the antiviral role of green tea catechins. Molecules. 2017;22(8):1337.

239. Menegazzi M, Campagnari R, Bertoldi M, Crupi R, Di Paola R, Cuzzocrea S. Protective effect of epigallocatechin-3-Gallate (EGCG) in diseases 
with uncontrolled immune activation: could such a scenario be helpful to counteract COVID-19? Int J Mol Sci. 2020;21 (14):5171.

240. Mhatre S, Srivastava T, Naik S, Patravale V. Antiviral activity of green tea and black tea polyphenols in prophylaxis and treatment of COVID-19: A review. Phytomedicine. 2020:153286.

241. Nguyen TT, Woo HJ, Kang HK, Nguyen VD, Kim YM, Kim DW, et al. Flavonoid-mediated inhibition of SARS coronavirus 3C-like protease expressed in Pichia pastoris. Biotechnol Lett. 2012;34(5):831-8.

242. Russo M, Moccia S, Spagnuolo C, Tedesco I, Russo GL. Roles of flavonoids against coronavirus infection. Chem Biol Interact. 2020:109211.

243. Tian Y, Bao Z, Ji Y, Mei X, Yang H. Epigallocatechin-3-gallate protects H2O2-induced nucleus pulposus cell apoptosis and inflammation by inhibiting cGAS/Sting/NLRP3 activation. Drug Des Devel Ther. 2020;14:2113-22.

244. Andres A, Donovan SM, Kuhlenschmidt MS. Soy isoflavones and virus infections. J Nutr Biochem. 2009;20(8):563-9.

245. Elfiky AA. Natural products may interfere with SARS-CoV-2 attachment to the host cell. J Biomol Struct Dyn. 2020:1-10.

246. Villena J, Kitazawa $\mathrm{H}$. The modulation of mucosal antiviral immunity by immunobiotics: could they offer any benefit in the SARS-CoV-2 pandemic? Front Physiol. 2020;11:699.

247. Morais AHA, Passos TS, Maciel BLL, da Silva-Maia JK. Can probiotics and diet promote beneficial immune modulation and purine control in coronavirus infection? Nutrients. 2020;12(6):1737.

248. Batiha GE, Beshbishy AM, Ikram M, Mulla ZS, El-Hack MEA, Taha AE, et al. The pharmacological activity, biochemical properties, and pharmacokinetics of the major natural polyphenolic flavonoid: quercetin. Foods. 2020;9(3):374

249. Colunga Biancatelli RML, Berrill M, Catravas JD, Marik PE. Quercetin and vitamin c: an experimental, synergistic therapy for the prevention and treatment of SARS-CoV-2 related disease (COVID-19). Front Immunol. 2020;11:1451

250. Glinsky GV. Tripartite combination of candidate pandemic mitigation agents: vitamin D, quercetin, and estradiol manifest properties of medicinal agents for targeted mitigation of the COVID-19 Pandemic defined by genomics-guided Tracing of SARS-CoV-2 targets in human cells. Biomedicines. 2020;8(5):129.

251. Pandey P, Rane JS, Chatterjee A, Kumar A, Khan R, Prakash A, et al. Targeting SARS-CoV-2 spike protein of COVID-19 with naturally occurring phytochemicals: an in silico study for drug development. J Biomol Struct Dyn. 2020:1-11.

252. Polansky H, Lori G. Coronavirus disease 2019 (COVID-19): first indication of efficacy of Gene-Eden-VIR/Novirin in SARS-CoV-2 infection. Int J Antimicrob Agents. 2020;55(6):105971.

253. Williamson G, Kerimi A. Testing of natural products in clinical trials targeting the SARS-CoV-2 (Covid-19) viral spike protein-angiotensin converting enzyme-2 (ACE2) interaction. Biochem Pharmacol. 2020;178:114123.

254. Abba Y, Hassim H, Hamzah H, Noordin MM. Antiviral activity of resveratrol against human and animal viruses. Adv Virol. 2015;2015:184241.

255. Han YJ, Ren ZG, Li XX, Yan JL, Ma CY, Wu DD, et al. Advances and challenges in the prevention and treatment of COVID-19. Int J Med Sci. 2020;17(12):1803-10.

256. Hooper PL. COVID-19 and heme oxygenase: novel insight into the disease and potential therapies. Cell Stress Chaperones. 2020.

257. Marinella MA. Indomethacin and resveratrol as potential treatment adjuncts for SARS-CoV-2/COVID-19. Int J Clin Pract. 2020:e13535.

258. McLachlan CS. The angiotensin-converting enzyme 2 (ACE2) receptor in the prevention and treatment of COVID-19 are distinctly different paradigms. Clin Hypertens. 2020;26:14
259. Wahedi HM, Ahmad S, Abbasi SW. Stilbene-based natural compounds as promising drug candidates against COVID-19. J Biomol Struct Dyn. 2020:1-10.

260. Lin CY, Yao CA. Potential role of Nrf2 activators with dual antiviral and anti-inflammatory properties in the management of viral pneumonia. Infect Drug Resist. 2020;13:1735-41.

261. Zan Y, Kuai CX, Qiu ZX, Huang F. Berberine ameliorates diabetic neuropathy: TRPV1 modulation by PKC pathway. Am J Chin Med. 2017:45(8):1709-23.

262. Nalli M, Ortar G, Schiano Moriello A, Di Marzo V, De Petrocellis L. Effects of curcumin and curcumin analogues on TRP channels. Fitoterapia. 2017;122:126-31.

263. Peixoto-Neves $D$, Soni H, Adebiyi A. CGRPergic nerve TRPA1 channels contribute to epigallocatechin gallate-induced neurogenic vasodilation. ACS Chem Neurosci. 2019;10(1):216-20.

264. Guo R, Zhou FM, Su CJ, Liu TT, Zhou Y, Fan L, et al. Epigallocatechin3-gallate attenuates acute and chronic psoriatic itch in mice: Involvement of antioxidant, anti-inflammatory effects and suppression of ERK and Akt signaling pathways. Biochem Biophys Res Commun. 2018:496(4):1062-8.

265. Yeh CM, Lin YJ, Hsu TH, Ruan T. Genistein suppressing the ROS-induced hypersensitivity of rat vagal lung C-fiber afferents through an ERalphamediated mechanism. Chin J Physiol. 2018;61 (1):14-24.

266. Kikuno S, Taguchi K, Iwamoto N, Yamano S, Cho AK, Froines JR, et al. 1,2-Naphthoquinone activates vanilloid receptor 1 through increased protein tyrosine phosphorylation, leading to contraction of guinea pig trachea. Toxicol Appl Pharmacol. 2006;210(1-2):47-54.

267. Nakamura T, Miyoshi N, Ishii T, Nishikawa M, Ikushiro S, Watanabe T. Activation of transient receptor potential ankyrin 1 by quercetin and its analogs. Biosci Biotechnol Biochem. 2016;80(5):949-54.

268. Li Z, Zhang J, Ren X, Liu Q, Yang X. The mechanism of quercetin in regulating osteoclast activation and the PAR2/TRPV1 signaling pathway in the treatment of bone cancer pain. Int J Clin Exp Pathol. 2018;11(11):5149-56.

269. Nakao S, Mabuchi M, Wang S, Kogure Y, Shimizu T, Noguchi K, et al. Synthesis of resveratrol derivatives as new analgesic drugs through desensitization of the TRPA1 receptor. Bioorg Med Chem Lett. 2017:27(14):3167-72.

270. Nalli M, Ortar G, Moriello AS, Morera E, Di Marzo V, De Petrocellis L. TRPA1 channels as targets for resveratrol and related stilbenoids. Bioorg Med Chem Lett. 2016;26(3):899-902.

271. Yu L, Wang S, Kogure Y, Yamamoto S, Noguchi K, Dai Y. Modulation of TRP channels by resveratrol and other stilbenoids. Mol Pain. 2013;9:3.

272. Terada Y, Masuda H, Watanabe T. Structure-activity relationship study on isothiocyanates: comparison of TRPA1-activating ability between allyl isothiocyanate and specific flavor components of wasabi, horseradish, and white mustard. J Nat Prod. 2015;78(8):1937-41.

273. Moran MM, Szallasi A. Targeting nociceptive transient receptor potential channels to treat chronic pain: current state of the field. Br J Pharmacol. 2018;175(12):2185-203.

274. Yang F, Zheng J. Understand spiciness: mechanism of TRPV1 channel activation by capsaicin. Protein Cell. 2017;8(3):169-77.

\section{Publisher's Note}

Springer Nature remains neutral with regard to jurisdictional claims in published maps and institutional affiliations. 